\title{
Why do socially responsible firms pay more dividends?
}

\section{Mohammed BENLEMLIH*}

April 2014

\begin{abstract}
Using a sample of 22,389 US firm-year observations over the period from 1991 to 2012, we find that high CSR firms pay more dividends than low CSR firms. This is consistent with our expectation that socially responsible firms may use the dividend policy to manage the agency problems related to overinvestment in CSR. The analysis of individual components of CSR provides strong support for this main finding: five of the six dimensions used in the analysis are also associated with high dividend payout, namely, corporate governance, community, diversity, employee relations, environment. Furthermore, by analyzing the stability of dividend payout, we find that socially irresponsible firms adjust dividends quicker than do socially responsible firms: dividend payout is more stable in high CSR firms than in low CSR firms. Additional results show that firms involved in two controversial activities: military and alcohol are associated with low dividend payout which is likely due to the high cost of external funding for these firms as highlighted by Goss and Roberts (2011). Our findings are robust to alternative assumptions and model specifications, alternative measures of dividend payout, additional control variables, and several approaches to address endogeneity and selection bias issues.
\end{abstract}

Keywords: Corporate social responsibility, dividend policy, agency theory

JEL classification: G32, M14

*PhD Candidate in Finance - Grenoble University - CERAG UMR CNRS 5820 - BP 47, 38040 Grenoble Cedex 9, France - Mohammed.benlemlih@upmf-grenoble.fr. 


\title{
Why do socially responsible firms pay more dividends?
}

\begin{abstract}
Using a sample of 22,389 US firm-year observations over the period from 1991 to 2012, we find that high CSR firms pay more dividends than low CSR firms. This is consistent with our expectation that socially responsible firms may use the dividend policy to manage the agency problems related to overinvestment in CSR. The analysis of individual components of CSR provides strong support for this main finding: five of the six dimensions used in the analysis are also associated with high dividend payout, namely, corporate governance, community, diversity, employee relations, environment. Furthermore, by analyzing the stability of dividend payout, we find that socially irresponsible firms adjust dividends quicker than do socially responsible firms: dividend payout is more stable in high CSR firms than in low CSR firms. Additional results show that firms involved in two controversial activities: military and alcohol are associated with low dividend payout which is likely due to the high cost of external funding for these firms as highlighted by Goss and Roberts (2011). Our findings are robust to alternative assumptions and model specifications, alternative measures of dividend payout, additional control variables, and several approaches to address endogeneity and selection bias issues.
\end{abstract}

Keywords: Corporate social responsibility, dividend policy, agency theory

JEL classification: G32, M14 


\section{Introduction}

In recent years, corporate social responsibility (CSR) has realized a great evolution in a way that companies have begun approaching CSR as a new strategy improving their image and competitive advantage; this may increase firm value as highlighted by Robinson et al. (2011) ${ }^{1}$.

The literature on CSR has evolved from focusing on the relationship between CSR and firm performance (e.g. Margolis and Walsh, 2003; Margolis, Elfenbein and Walsh, 2007), to several other relevant topics in corporate finance such as the impact of CSR on the cost of capital (El Ghoul et al., 2011); the capital structure for socially responsible firms (GirerdPotin et al., 2011); the effect of CSR on information asymmetry (Dhaliwal et al., 2011). In order to further extend this literature, this paper focus on the impact of CSR on dividend policy: one of the major financial decisions for most firms. Dividends are considered as the most commonly used payout device in the corporate world. Since the dividend irrelevance theory of Miller and Modigliani $(1961)^{2}$, extensive prior theoretical and empirical work has suggested different explanations of the dividend policy puzzle, namely, the agency theory (e.g. Kalay, 1982), the bird in hand theory (e.g. Gordon, 1963; Lintner, 1962), the signaling theory (e.g. Ross, 1977), and the life-cycle theory (e.g. Fama and French, 2001). Despite substantial research, the dividend puzzle is far from being solved, even in the US context (Shao et al., 2010).

Motivated by the importance of the dividend policy in corporate finance as well as the growing interest in CSR, this paper aims to define how dividend policy is influenced by firm CSR level. Several theoretical arguments can be put forward to explain why CSR activities may exercise an effect on firm dividend policy. First, managers have private benefits from being identified as socially responsible, which may encourage them to overinvest in social and environmental activities to increase their reputation, especially when they have access to

\footnotetext{
${ }^{1}$ The mechanisms through which CSR affect firm value are multiple: CSR help increasing firm's reputation and avoid investors explicit claims (McGuire et al., 1988); employees have high motivation and may accept low compensation when working for good reputation firms which may reduce firm risk (Berk et al., 2010), the cost of capital (El Ghoul et al., 2011), and the level of debt (Bae et al., 2011); customers are more likely to pay premium prices for firms with good reputation since this good reputation is considered as a signal for product quality (Fombrun and Shanely, 1990).

${ }^{2}$ Miller and Modigliani (1961) argue that the firm value depends only on the profitability of its assets, but not on the amount of dividends paid to shareholders: dividend policy does not affect firm value.
} 
high cash in place (Barnea and Rubin, 2010). Dividend payout may help controlling for this agency problem by reducing the cash in place which undoubtedly avoids overinvestment in CSR. Second, according to the stakeholders' theory (Freeman, 1984), firms' objective have to take into account the ethical aspect of wealth creation and to meet all stakeholders expectations. The stakeholders' theory also provides support for the fairness and ethics of wealth distribution between those who have contributed to its creation. We expect then that socially responsible firms are fairer and transparent when it comes to dividend payout. Third, socially responsible firms are generally in their mature stage of their life-cycle as highlighted by Attig et al. (2013). Based on that and on the life-cycle theory of dividends (e.g. Fama and French, 2001) suggesting that firms tend to pay more dividends in their mature stage, we expect that high CSR firms are more likely to pay high dividends. Building on these three theoretical arguments, we then hypothesize that ceteris paribus, firms with high CSR performance pay more dividends than firms with low CSR performance.

Using a sample of 22,389 US firm-year observations representing 3,040 unique U.S. firms between 1991 and 2012, and after controlling for previous determinants of dividend policy as well as industry and year fixed effects, we find that high CSR firms pay more dividends than low CSR firms providing strong evidence for our earlier hypothesis. Furthermore, the analysis of individual components of CSR is consistent with our main result: five of the six dimensions used in the analysis are also associated with high dividend payout, namely, corporate governance, community, diversity, employee relations, environment. We also investigate the stability of dividend payout, another interesting question in our context. We expect that, ceteris paribus, dividend payout in socially responsible firms should be more stable than that in socially irresponsible firms. Using the same sample as above and an extension of Lintner' model (1956) commonly used in dividend smoothness studies (e.g., Von Eije and Megginson 2008), we find that low CSR firms adjust dividends quicker than do high CSR firms: the dividend policy is more stable for firms with high CSR score. Finally, by analyzing the controversial areas provided by KLD, we find that firms involved in two controversial activities, namely, military and alcohol are associated with low dividend payout. We think that those firms reduce their dividend payout to finance their projects internally because of the high cost of external funding as highlighted by Goss and Roberts (2011). To check the robustness of our results, we further run a battery of sensitivity tests, including alternative assumptions and model specifications, alternative measures of dividend payout, additional control variables, instrumental variables, propensity score matching, and the 
Heckman Selection Model to address endogeneity and selection bias issues; all of which have confirmed our findings.

Our study contributes to the literature in several ways. First, this is the first paper to our knowledge to study the effect of CSR on dividend policy, one of the most debated questions in modern corporate finance. Studies on the relationship between CSR and financial performance are different and provide evidence that social performance enhances firm' wealth; it is thereby relevant to investigate the distribution of this wealth. Second, we extend prior research on the factors affecting the dividend policy such as corporate governance (Mitton, 2004), the national culture (Shao et al., 2010), and family or state ownership (He, Li, and Tang, 2012) by showing that high CSR score is associated with high dividend payout. Third, we add to the literature on "sin" stocks (Hong and Kacperczyk, 2009) by showing that firms related to military and alcohol pay less dividends and may prefer to keep cash to finance their investment internally, since they are more likely to face difficulties to use external funding.

The remainder of this article will be as follows. In the next section, we review prior literature on dividend policy; we then develop our theoretical arguments for the relationship between CSR and dividend policy as well as our main hypotheses. In the fourth section, we present the data and the research design. The fifth section discusses the main results of the study. Robustness tests are reported in the sixth section, before we conclude in the seventh section.

2. Literature review on dividend policy theories

The financial theory presents an extensive theoretical and empirical literature related to the firm's dividend policy choices. In this section, we briefly introduce some of these theories on dividend payout, particularly, those which are relevant to justify the relationship between CSR and dividend policy: the bird in hand theory, the signaling theory, the agency theory, and the life-cycle theory.

\section{Bird in hand theory}

Contrary to the dividend irrelevance theory of Miller and Modigliani (1961) suggesting that dividend policy employed by the firm does not affect its value and that investors are indifferent between receiving cash dividends now and future payoffs from capital appreciation, the bird in hand theory (Gordon, 1963; Lintner, 1962) confirms that the firm value is affected by dividend policy. Suppose that investors view distant dividend payments 
as riskier than current payments, might they not prefer a bird in hand to two in the bush? In other words, under conditions of uncertainty, rational investors will have preference for cash and close dividends, particularly when shares sale cannot take the place of dividends in meeting investors' cash needs because of ownership dilution phenomenon. Investors would have a preference for dividends as it is more certain than capital gain that might or might not appear if the earnings are retained; they then value high payout firms more highly than low payout firms.

\section{Signaling theory}

When insiders have more information on the future prospects of their firms than outsiders, changes in the capital structure of the firm may be used as signals. For example, Ross (1977) highlights that the increase of debt level in capital structure will provide an unambiguous signal to the market regarding the positive prospects of the firm. This signaling concept is easily applied in the context of dividend policy. Bhattacharya (1979), Miller and Rock (1985), and John and Williams (1985) point out that managers use dividend changes to issue direct signal to the market regarding the future results of the firm. An increase in dividend payout serves as an indicator informing the market about the increase of the expected results compared to the previous year results in a way to meet debt payments and dividend payments without increasing the probability of default. For Ross (1977), and Hakansson, (1982) managers have better information on the results and the growth prospects of the firm than outsiders: when the firm is undervalued by the market, the dividend can be used to reflect the true value of the firm, knowing that signaling by dividend payments is costly and difficult to imitate by firms with poor growth prospects. Several empirical studies confirm this approach; they also provide evidence that analysts revise their earnings forecasts because of the announcement of an unexpected dividend change by an amount positively related to the size of the unexpected dividend change (e.g. Ofer and Siegel, 1987).

\section{Agency theory}

According to the agency theory, there is no reason to believe that managers will always act in the best interest of shareholders. The owner should incur some monitoring costs in order to keep the agent in line. On one hand, low dividend payout policy maximizes managers flexibility and increase the size of total assets under their control. Jensen and Meckling (1976), Kalay (1982), and Jensen (1986) highlight that high dividend payout could help 
controlling the agency costs of free cash flow by reducing the resources under managers' control. On the other hand, for a given dividend policy, managers are responsible for maintaining the same investment policy by searching the necessary funding. Easterbrook (1984) shows that when firms pay high dividend, managers use external funding which requires the implementation of an audit and monitoring procedure in the firm. The distribution of dividends is considered by shareholders as an implicit mechanism that lets managers with little free cash to invest in negative net present value projects. High dividends payment is useful in controlling two types of agency costs: the cost of monitoring managers and the cost of risk aversion on the part of managers. The use of dividend policy as a mechanism to mitigate agency problems between managers and majority shareholders has also been demonstrated empirically (e.g. Lewellen, 1981).

\section{Life-cycle theory}

According to the life-cycle theory of dividends (e.g. Mueller, 1972; Fama and French, 2001), the dividend policy is particularly related and evolves over the different life-cycle stages of the firm. Firms in early stages of their life cycle have access to more growth opportunities, but, they also have little ability to generate sufficient internally cash to meet all their financing needs and in the same time to pay dividends. Furthermore, access to external funding can be harder because of flotation costs, personal taxes, or informational asymmetries. As a result they will largely avoid payout and choice to fund their attractive investment projects. After a period of growth, firms reach the stage of maturity in their life cycle (they are old, large, profitable and with more retained earnings): in this stage, the cash internally generated by the firms is higher than the cash can profitably be invested. Eventually, it becomes optimal for these firms to distribute their earnings to shareholders and pay more dividends. Distribution becomes more important in this mature stage because letting substantial cash accumulate internally can lead to agency costs of the free cash flows.

\section{Corporate Social Responsibility and dividend policy}

To justify the main hypothesis of this work stating that socially responsible firms are likely to pay more dividends, three main arguments are developed: they are based on the agency theory, the stakeholders theory, the bird in hand theory, and the life cycle theory.

First, based on the agency theory, dividend payout plays a major role in controlling the agency cost of free cash flow. As we mentioned earlier, the payout helps reducing resources 
under managers control, and subsequently reduces a potential inefficient use of firm' resources by managers. In the CSR context, the agency conflict is particular since not only managers, but all the insiders have interest in increasing social performance (managers, blockholders who are not part of the daily management team, and directors). By assuming that different shareholders may have different interests with respect to CSR, Barnea and Rubin (2010) point out that insiders gain private benefits from being part of high social performance firms. In their study of corporate philanthropic practices, Brown et al. (2006) indicate that donations may enable managers and directors to be identified as socially responsible at shareholders expenses. Such programs are also likely to enhance insiders' reputations and provide them with other benefits (gifts, tickets to events, access to celebrities, new network, etc.). For Brown et al. (2006), unless this cost of giving is offset by reduced compensation, corporate philanthropy may represent an agency cost: insiders would have to pay the cost associated with the non-value-creating CSR activity (Barnea and Rubin, 2010). In the absence of monitoring mechanisms, and in the presence of low insiders ownership, insiders may induce firms to increase their CSR commitment to a level higher than that which maximizes the firm's value. This could lead to an over-investment in social and environmental activities particularly when firms have access to high cash in place. When insiders are obliged to use external funding, they are more worried about the return of their investment in a way to avoid CSR overinvestment. Banks and debt holders have the power to influence decisions and play a monitoring role as highlighted by Gilson (1990) who emphasizes that with the bank increased monitoring, significant internal changes take place in the board of direction ${ }^{3}$. Adopting an optimal dividend policy helps to reduce the cash in place for managers and is likely to discourage them to over-invest in CSR.

Second, based on the stakeholders theory (Freeman, 1984), ${ }^{4}$ and on good management hypothesis of CSR (Waddock \& Graves, 1997), firm objective has exceeded the framework of maximizing shareholders' wealth by integrating the ethical aspect of wealth creation and the satisfaction of all stakeholders. Beyond the fact that firm is encouraged to behave and create its wealth ethically and in a sustainable way keeping the interest of customers, suppliers, employees, communities, and shareholders aligned and going in the same direction; another

\footnotetext{
${ }^{3}$ Gilson (1990) demonstrates that on average, only $46 \%$ of directors who sit on boards prior to financial distress and $43 \%$ of the CEO are still present when their firms emerge from bankruptcy.

${ }^{4}$ For Freeman (1984), stakeholders are: "Any group or individual who can affect or is affected by the achievement of the organization's objectives"
} 
responsibility of CSR firms is to integrate the perspective of the fairness and ethic of wealth distribution between those who have contributed to its creation ( $\mathrm{He}, \mathrm{Li}$, and Tang, 2012). Furthermore, based on the bird in hand theory, even by investing in CSR firms, rational investors have high preference for cash and close dividends. They are more demanding when it comes for socially responsible firms' dividends. In fact, firms with high CSR scores are likely to be more wealth created and more transparent: investors expect that socially responsible firms' dividend policy is more likely to reflect this transparency. High dividend payment may strengthen firms reputation and improve their image as socially responsible actors.

Third, based on the life cycle theory, mature firms, because of their high profitability and the few investment opportunities they have, generate cash higher than the cash can be profitably invested. Thereby, they are more likely to pay dividends in order to avoid substantial agency costs of free cash flow. From a CSR perspective, mature firms with high management skills and high resources may be more likely than younger firms to invest strategically in CSR activities (Attig et al., 2013). Thus, high social performance is likely to be associated with older firms because they have the experience necessary to be involved in such activities. We then expect that high CSR firms are more likely to adopt a strategy of high dividend payout since they have reached their mature stage of their life cycle which allows them to have access to more free cash. Based on these three elements, the main hypothesis of this work is as follows:

\section{H1: high CSR firms pay more dividends than low CSR firms, ceteris paribus.}

The use of an overall CSR score might mask the effect of each CSR dimension in determining the firm dividend policy. Galema, Plantinga and Scholtens (2008), and Attig et al. (2011) indicate that the difference in results regarding some CSR studies may be due to the use of aggregate CSR measures. When considering the relationship between CSR and dividend policy, we can expect that some individual components of CSR score are more relevant and may have a positive impact on dividend payout than others. First, given the importance of governance mechanism in agency theory, one might argue that the higher is the governance score, the more the firm use dividend policy to control the phenomenon of over-investment in CSR. Based on the outcome model of dividends (La Porta et al., 2000), corporate governance score should be positively related to dividend payout. Better-governed firms offer stronger protection rights to their shareholders. Thereby, shareholders will pressure managers to pay 
high dividends. We then expect a positive relationship between governance and diversity scores (diversity score also reflects some aspects of good governance). Second, Brown et al. (2006) emphasize that highly visible companies that may face litigation risks or those which participate in industries impacting the environment have high reputation for giving back to the community as this may generate friendlier treatment by regulators. Community score is the KLD dimension that reflects the most firms giving, ${ }^{5}$ we anticipate then that high community involvement may be due, inter alia, to high charitable giving practices. High dividends payment is likely to play a role in controlling donations strategy, which explains our expectation for a positive effect of community score on dividend payout. Finally, we think that some other components of CSR such as environment, employee relations and product characteristics may be less relevant for dividend policy. These components are more likely to improve not only managers' reputation but rather firm reputation. We thereby expect that high investment in environment and product characteristics does not affect dividend policy. Accordingly, the second hypothesis of this work is as follows:

\section{H2: only some individual components of CSR are relevant for dividend policy}

Now, we move on to consider the stability of dividend payout: the third main analysis of this work. First, as highlighted by Easterbrook (1984), one of the most important conditions for dividend policy to serve as a disciplinary device for reducing the agency costs is the stability of dividends payment. According to our expectation in the first hypothesis, dividends are more likely to play a role in controlling the agency costs for firms with high CSR score. Thereby, socially responsible firms should adjust dividends less quickly than socially irresponsible firms; this explains that the dividend payout is likely to be more stable in high CSR than in low CSR firms. Second, if high CSR firms pay more dividend than low CSR firms (as stated in the first hypothesis), managers in low CSR firms would retain more cash flow than those retained in high CSR firms. Managers, in low CSR firms would have more resources to manipulate, e.g. to increase their dividend payout, than managers in high CSR firms (He, Li, and Tang, 2012). Low CSR firms are, then, more likely to increase their dividend payout in order to signal their true value when the market undervalues their equity. Therefore, the managers in socially irresponsible firms will frequently adjust the level of dividend payout to reflect a better value of their firms, unlike socially responsible firms which do not need to use the dividend policy as a signal. Finally, our discussion on the stability of

\footnotetext{
${ }^{5}$ We present more information about individual CSR score in appendix A
} 
dividend payout between high and low CSR firms would be strengthened by the characteristics of high CSR firms such as the reputation of efficient cost control and the optimal use of resources. CSR firms may prefer more stable dividend policy in order to signal their transparency and high management. We then formulate the third hypothesis of this work as follows:

H3: dividends policy is more stable in high CSR firms than in low CSR firms.

4. Data and research design

\subsection{Sample selection}

To investigate the relationship between CSR and dividend policy, our sample is drawn from two data sets: Compustat, which provides financial statement data, and MSCI ESG STATS (formerly known as KLD STATS), which provides CSR data. To construct our sample, we begin with all firms from Compustat for the period ranging between 1991 and 2012 with nonmissing financial information. We exclude from our sample financial firms (SIC codes between 6000 and 6999) and utility firms (SIC codes between 4900 and 4999) because they are regulated entities. We also eliminate firms with abnormally high dividend payout (i.e., higher than earnings or net sales). Next, we match our Compustat sample with MSCI ESG STATS, which evaluates each firm along 13 CSR areas based on annual reports, public information, global media publications, government documents, academic journals, and business surveys. Our final sample contains 22,389 observations between 1991 and 2012. Table 1 presents the sample composition by year and by industry (using the two-digit Standard Industrial Classification). The sample distribution by year shows that the firms' number in our study is fairly distributed around 300 firms between 1991 and 2000, 500 firms between 2001 and 2002, before increasing dramatically to between 1600 and 2000 firms between 2003 and 2012. The increased firms number in our sample is mainly due to the increase of firms' number covered by KLD after 2003. The sample distribution by industry is based on the first two digits of the SIC code. As expected, the table shows that manufacturing industries have the largest number of observations with 12,091 observations and more than $50 \%$ of our sample. The other industries, particularly mineral industries, transportation, trade, and service industries, all of them have an important number of observations and a good representation in our sample. 


\subsection{Regression variables ${ }^{6}$}

\subsubsection{CSR data}

Our original sample is drawn from MSCI ESG STATS, a database compiled by MSCI ESG Research and its predecessor, KLD Research \& Analytics Inc. Since its founding in 1988, KLD has been providing research, analysis, and consulting services related to environmental, social, and governance practices. Its rating is considered as a standard in CSR and has been widely used by researchers (e.g., Wood, 1995; Sharfman, 1996; Hillman and Keim, 2001; Waddock, 2003; Chatterji et al., 2009; Jo and Harjoto, 2011). The number of firms covered by KLD has increased over time. The database covered around 650 firms between 1991 and 2000, 1,100 firms in 2001 and 2002, and 3,100 firms from 2003 to 2007 (Bouslah, 2013). KLD rating consists of 13 CSR dimensions, grouped into two major categories: seven qualitative issue areas and six controversial business issues. The seven qualitative issue areas include: community, diversity, employee relations, environment, product characteristics, human rights ${ }^{7}$, and corporate governance. The six controversial business areas include: alcohol, gambling, firearms, military, nuclear power, and tobacco. The qualitative issue areas include positive and negative ratings (strengths and concerns) with a binary system (0/1) for every concern and strength as illustrated in Panel A of Appendix A. The controversial areas include only negative ratings (concerns) with a binary system for whether a firm is involved in one or more concerns (more details in Panel B of Appendix A). Because qualitative issue areas and controversial business areas are inherently different, we examine them separately. We first calculate an overall CSR score based on six different CSR areas, namely: community, diversity, employee relations, environment, product characteristics and corporate governance. For each qualitative area, we calculate a score equal to the number of strengths minus the number of concerns. We then sum the qualitative area's scores to obtain our overall

\footnotetext{
${ }^{6}$ Appendix A and B provides definitions for all variables used in the analysis, including dependent variables, CSR variables, control variables, alternative and additional variables used in the robustness tests.

${ }^{7}$ KLD has assessed firms in the area of human rights since 1995. These dimensions are not available before 1995, thus we follow Kim at al. (2012) and Galema et al. (2008) by excluding this dimension in constructing our overall CSR score. Our main result remains unchanged when we include the human rights area in the calculation of our overall CSR measure. Our result remains also unchanged when we use Servaes and Tamayo's (2013) definition of CSR, by excluding corporate governance from our overall CSR score.
} 
score (CSR_NET). This approach is widely used in the CSR literature (e.g., El Ghoul et al., 2011; Goss and Roberts, 2011; Attig et al., 2013). More detailed variable definitions are provided in "Appendix A."

Table 2 provides an overview of the descriptive statistics for CSR data. Panel (A) reports different statistics for the overall CSR score as well as for the individual components of CSR. All the scores present a median equal to 0 (except for the overall CSR score, the median equals to -1) which suggests that the distribution of CSR scores is relatively balanced with positive and negative values. Panel (B) represents the overall CSR score over time. The statistics indicate that the overall CSR score has exhibited non-negligible variation over time, ranging from a minimum of -9 to a maximum of 18 .

\subsubsection{Dependent variables}

Studies on dividend policy focus on three fundamental questions: payout ratio (e.g., Faccio et al., 2001; La Porta et al., 2000), payout propensity (payer or nonpayer, for example, Denis \& Osobov, 2008); and the stability of dividends payment (e.g., Aivizian et al., 2003). This study adds to the first and the third line of research by focusing on how CSR affect dividend payout as well as the stability of dividend payment. The second line of research is marginally treated in the robustness tests section.

To test the first and the second hypothesis of this work on the relationship between CSR and dividend policy, we use two main constructs to measure dividend payout: the ratio of cash dividends on common stocks ${ }^{8}$ to net sales (e.g. La Porta et al., 2000; Brockman and Unlu, 2009; Chay and Suh, 2009), and the ratio of cash dividends on common stocks to total assets (e.g. Aivazian et al., 2003; Shao et al., 2010). We scale cash dividends by net sales and total assets instead of earnings and market capitalization for several reasons ${ }^{9}$. First, earnings have the potential problem to be easily manipulated by accounting tricks so that the figures match a pre-determined target. Second, La Porta et al. (2000) indicate that the diversion of resources

\footnotetext{
${ }^{8}$ Fenn and Liang (2001), Brav et al. (2005), and Deshmukh et al. (2013) also employ cash dividends on common stocks. Our core findings remain robust to using total cash dividends (common dividends plus preferred dividends) instead of common dividends.

${ }^{9}$ We avoid to use the ratio of cash dividends to earnings and to market capitalization for the reasons developed hereafter. However, all our core results continue to hold when we measure dividend payout using dividends to earnings and dividends to market capitalization.
} 
may occur before earnings are reported in which case the ratio of dividends to earnings overestimate the share of true earnings that is paid out as dividends. Third, when earnings are negative, the ratio becomes meaningless. This problem could be solved by eliminating firmyears with negative earnings; however, such remedy reduces the sample size by more than $12.75 \% .{ }^{10}$ Fourth, when earnings are low, this may lead to an instability payout ratio which could bias the results. Finally, the use of cash dividends to market capitalization ratio could lead to pricing problems that may exist because of low share price. As a guard against all these problems related to earnings and market capitalization, we prefer to use cash dividends to net sales and to total assets especially that net sales are independent on accounting conventions and that total assets are less subject to manipulation and theft.

Panel A in Table 3 provides descriptive statistics for the main dependent variables and shows that more than $50 \%$ of firms in our sample are not dividend payers.

\subsubsection{Control variables}

To better isolate the effect of CSR variables on dividend policy, we control for a set of potential variables commonly used in prior studies on firm dividend policy (e.g. Smith and Watts, 1992; Faccio et al, 2001; Fama and French, 2001; Von Eije and Megginson 2008). The set of control variables includes:

Firm size (SIZE) is calculated as the natural logarithm of the dollar value of total assets. According to the life cycle theory, firm size and dividend payout are positively correlated. Large firms tend to be more mature, less risky, and have access to high free cash flow. Furthermore, they also can use external funds to finance their business with low cost. Thus, larger firms have high flexibility in paying more dividends.

Cash holdings $(\mathrm{CASH})$ is measured by the cash and short-term investments scaled by total assets. On one hand, in the presence of agency conflicts, the cash in place and the short term investments are increased by managers which reduce the dividends payment. Thus a negative relationship is expected between dividend payout ratios and the cash holdings. On the other hand, managers might use dividends to mitigate the agency costs of free cash flows. In this case, the relationship between dividend payout and cash holdings should be positive.

\footnotetext{
${ }^{10}$ We re-run all tests using the reduced sample with dividends scaled by earnings. Our results are similar to those reported herein for dividends scaled by sales and assets.
} 
Growth opportunities (GROWTH) are estimated as the logarithm of sales growth over the previous year. The life cycle theory suggests that firms with high investment opportunities will retain earnings in order to finance theses opportunities, while firms with low investment opportunities will have access to high cash flow and tend to pay more dividends. Thus, we expect a negative relationship between growth opportunities and dividend payout ratio.

Leverage (DEBT) is the book value of total liabilities scaled by the book value of total assets. We expect a negative association between leverage and dividends payment. Borrowing ratio is more likely to affect dividend policy because of the potential monitoring role of debt on managers. Firms with high leverage ratio are financially constrained by their lenders; this explains their low ability to pay high dividends.

Profitability (ROA) is measured by net income to book value of assets. High profitability firms are more likely to generate free cash flows and thus to make higher dividend payout. According to the life cycle theory, mature firms are more profitable and are more inclined to dividend payment. We then expect a positive association between profitability and dividend payout ratios.

Life cycle proxy $\left(R E \_T E\right)$ is calculated as the ratio of retained earnings to book value of common equity. The life cycle theory states that the cash generated by firms in their mature stage is higher than the cash can be profitably invested. After years of successful business, they accumulate high profit (high retained earnings to common equity ratio) and tend to pay high dividends. On the other side, young firms face large investment opportunities with high need of cash flows which leads to low retained earnings to common equity ratio. Thus, we use the ratio of retained earnings to total equity as proxy for firm life cycle and expect a positive association between this proxy and dividend payout.

Additional control variables. Several additional control variables are used in the robustness tests section to ensure that our analysis does not suffer from any omitted variables bias, these additional control variables include: taxes (TAXE), a dummy variable that takes the value of one if the firm has a tax advantage from its previous years and zero otherwise. Research and development ratio (R_D) calculated as the research and development expenditures to total assets, is another proxy for firm growth possibilities. The volatility of the profitability (SROA) equals to the standard deviation of the return on assets (ROA) over the previous five years. Firm's age (AGE) is calculated as the number of years between the fiscal year and the 
first listing in the database. Market to book ratio (MTB) is calculated as the book value of total assets minus the book value of equity plus the market value of equity scaled by the book value of total assets. We expect that firms with high tax advantage, high research and development ratio, and high return on assets volatility pay fewer dividends, while older firms with high market to book ratio tend to pay high dividends.

Panel B in Table 3 shows that on average our sample includes mature (median retained earnings as a percentage of assets 50\%), profitable (median ROA 5\%), liquid (median cash holdings as a percentage of assets $11 \%$ ), and slow growth firms (median net sales growth rate $8 \%)$.

Panel $\mathrm{C}$ in Table 3 reports descriptive statistics for all the variables used in the robustness tests section.

\subsection{Research methodology}

To study the relationship between CSR and dividend policy, we use two main approaches: the first one is univariate based on the comparison tests and the second one is multivariate based on the regression models. In a second stage, we also use Lintner's model regressions (1956) to investigate the stability of dividend payout for CSR and non CSR firms.

\section{CSR and dividend policy}

First, through the univariate approach, we compare the mean and the median for our main measures of dividend policy (as well as for the additional dependent variables used in the robustness tests) between socially responsible and non-responsible firms.

Second, through the multivariate approach, we run regressions of dividend policy measures on the overall CSR score (also on individual components of CSR scores) and other control variables as defined below ${ }^{11}$ :

Dividend $_{i t}=\alpha+\beta_{1} \times C S R_{i t}+\beta_{2} \times S I Z E_{i t}+\beta_{3} \times C A S H_{i t}+\beta_{4} \times G R O W T H_{i t}+\beta_{5} \times$ $D E B T_{i t}+\beta_{6} \times R O A_{i t}+\beta_{7} \times R E_{-} T E_{i t}+$ INDUSTRY FIXED EFFECTS + YEAR FIXED EFFECTS $+\varepsilon_{i t}$

\footnotetext{
${ }^{11}$ In our main analysis, we use contemporaneous values of CSR measures, firm dividend payout, and control variables. We obtain similar results when we use contemporaneous values of firm dividend payout and control variables, but lagged values CSR measures.
} 
Where Dividend ${ }_{\text {it }}$ is measured as cash dividends scaled by net sales (and by total assets); $\alpha$ is the time invariant intercept; $\beta$ s are the slope coefficients of the respective factors; $\mathrm{CSR}_{\mathrm{it}}$ represents social responsibility scores, it is measured by the overall CSR score (CSR_NET) as well as by individual components of CSR: corporate governance (CGOV_NET), employee relations (EMPL_NET), diversity (DIV_NET), community (COM_NET), product characteristics (PRO_NET), and environment (ENV_NET); SIZE it $_{\text {it }}$ is the natural logarithm of the dollar value of total assets; $\mathrm{CASH}_{\mathrm{it}}$ is measured by the cash and short-term investments scaled by total assets; GROWTH ${ }_{\text {it }}$ is the logarithm of sales growth over the previous year; $\mathrm{DEBT}_{i t}$ is the book value of total liabilities scaled by the book value of total assets; $\mathrm{ROA}_{i t}$ is the return on book value of assets; $\mathrm{RE}_{-} \mathrm{TE}_{\mathrm{it}}$ is the ratio of retained earnings to book value of common equity, all referring to firm $\mathrm{i}$ in year $\mathrm{t}$, and cit is the respective disturbance term.

We include industry dummy variables to control for industry fixed effects, which may affect the relationship between firms' dividend policy and social performance scores. Industry dummy variables are based on the first two digit of the Standard Industrial Classification (SIC). We also include dummy variables for each year in our sample period (i.e., year-fixed effects) to control for changing economic conditions. We use ordinary least squares (OLS) specifications with robust standard errors adjusted for both heteroskedasticity and clustering of observations. More precisely, we use one way cluster robust standard errors approach of Petersen (2009) at the firm level.

\section{CSR and the stability of dividends payment}

To test the third hypothesis on the dividend stability in CSR -versus non CSR- firms, we adopt a statistical approach similar to the one built by Lintner (1956). The model of Lintner (1956) is widely used by researchers to examine the dividend smoothness. By testing different dividend prediction models, Fama and Babiak (1968) conclude that Lintner's model performs better than other models in terms of explanatory power. In line with this conclusion, Benartzi et al. (1997) demonstrate that Lintner framework is the best model of dividend-setting process. Studies on dividend stability using this framework are multiple and include Shevlin (1982), Brav et al. (2005), Robinson (2006), and Von Eije and Megginson (2008). Then we calculate the following Lintner model regressions for cash dividends: 


$$
\Delta \operatorname{Div}_{i, t}=\alpha_{i, t}+\beta_{1 i} D_{i, t-1}+\beta_{2 i} E_{i, t}+\mu_{i, t}
$$

Where:

$\Delta D i v_{i, t}=$ the changes in annual cash dividends from year $\mathrm{t}-1$ to year $\mathrm{t}$

$D_{i, t-1}=$ the lagged value of cash dividends.

$E_{i, t}=$ earnings before interest but after tax for year $\mathrm{t}$.

$\mu_{i, t}=$ the error term of the equation.

We add to the equation industry and year fixed effects (the industry fixed effects are based on the first two digit of the Standard Industrial Classification), and we estimate the model using robust standard errors clustered at the firm level (Petersen, 2009). Furthermore, in order to compare the stability of dividend payout between high and low CSR firms, we split the sample into high and low CSR firms, with low CSR firms are those with negative overall CSR score and high CSR firms are those with positive overall CSR score.

Lintner' model indicate that instead of moving immediately to the new target dividend, firms smooth out changes in their dividends by moving a part of the way to the target each year. The speed-of-adjustment (SOA) measures the speed with which firms adjust their dividends, it is estimated as $-\hat{\beta}_{1}$, and higher value of SOA indicates a speedier adjustment and subsequently less stable dividend payout. The target payout ratio (TPR) measures the importance of targeting the dividends payment, it is estimated as $-\hat{\beta}_{2} / \hat{\beta}_{1}$.

\section{Empirical evidence}

The main purpose of this work is to identify the relationship between CSR and firm dividend policy. We use a sample of 22,389 U.S. firm-year observations ranging between 1991 and 2012 and we run our analyses. In section 5.1, we present results from the univariate analysis comparing the dividend level of socially responsible versus socially irresponsible firms. In section 5.2, we use regression models to better control the effect of other variables and isolate the real link between CSR score and dividend policy. Finally, we study the stability of dividend payout for socially responsible and irresponsible firms in section 5.3.

\subsection{Univariate tests}

In Table 5 Panel A, we compare the mean and the median for dividend variables between firms with high and low social responsibility level. Socially responsible firms are defined as 
firms with positive overall CSR score, while socially irresponsible firms are those with negative overall CSR score. Regarding the two main measures of dividend in our analysis: cash dividends to net sales and cash dividends to total assets, they are both higher for socially responsible firms. The difference is about $22.22 \%$ for the first measure and $37.5 \%$ for the second one. The difference is statistically significant in both cases at the $1 \%$ level, providing support for our main hypothesis and suggesting that socially responsible firms pay more dividends than socially irresponsible firms. This result is confirmed when we use the two other dividend payout ratios (cash dividends to net income, and cash dividends to market capitalization).

We also study the difference in control variables between socially responsible and irresponsible firms. Table 5 Panel B shows that globally CSR firms are larger, with higher cash ratio, lower growth opportunities, and debt ratio. They are also more profitable with higher ratio of retained earnings to book value of common equity. All the results in the univariate analysis are significant at the $1 \%$ level.

Finally, we draw graphs representing the dividend payout ratios over the period of the study between 1991 and 2012. Graph 1 shows that socially responsible firms pay more dividends, this finding is consistent across the whole study period. The same result is found when we use the second ratio of dividend payout. Generally, our preliminary analysis is consistent with the first hypothesis of this work suggesting that firms with high overall CSR score pay more dividends than low overall CSR score firms.

After the preliminary analysis based on the univariate tests, we then move to the multivariate analysis in order to control for the explanatory variables suggested by the literature on dividend policy.

\subsection{CSR and dividend policy: main evidence}

Table 6 reports the results of estimating equation (1) using ordinary least squares (OLS), with standard errors corrected for heteroscedasticity and clustering by firm to account for the lack of independence of observations within a given firm over time. In Model 1, we regress dividend payout (DIV_SALES) on overall CSR score (CSR_NET) without taking into account control variables. We find support for our hypothesis claiming a positive relationship between CSR and dividend payout: the estimated coefficient on CSR_NET is positive and statistically significant (at the 1 percent level), indicating that an increase in overall CSR score 
leads to higher dividend payout. This first result is confirmed in Model 2 when including potential determinants of dividend payout issued from prior literature: high overall CSR score is positively associated with high dividend payout. Furthermore, in line with prior studies (e.g. Fama and French, 2001; Denis and Osobov, 2008; Von Eije and Megginson, 2008), we document several statistically significant relations in our control variables: growth measure negatively affects dividend policies suggesting that firms with high growth opportunities are associated with low dividend payout; firm' size and retained earnings are positively related to dividend payout suggesting high level of dividends for large firms with high retained earnings ratio. Additionally, the variable capturing profitability is positively and statistically related to dividend policy providing some evidence that profitable firms tend to pay more dividends. Firm leverage is negatively and statistically associated with dividend payout (only with the second ratio of dividend payout) providing evidence that firms with high debt level have low ability to pay high dividends. Finally, cash and short term investments variable does not have a significant effect on dividend payout.

We then examine the stability of our main result across different subsample periods. This test allows us to check whether changes in firm level and macroeconomic factors affect the relation between CSR and dividend policy over time. We thereby re-estimate our main model (Model 2) after splitting the total sample into four sub-sample periods: 1991-1996, 1997 2002, 2003-2007, and 2008-2012. During the 1991-1996 subsample period, the coefficient on CSR_NET is positive but statistically insignificant suggesting no significant link between overall CSR score and dividend payout, this may be due to the low number of firms in our sub-sample during this first period because of the low firm coverage by KLD. In the three other sub-samples periods, the coefficient on CSR_NET is significantly positive providing support for initial result: high overall CSR score is positively associated with high dividend payout. Thus, we conclude that the link between overall CSR score and dividend policy is consistent over time.

Table 6 (Models 7-12) also presents the analysis of dividend payout measured by the ratio of cash dividends to total assets our second main measure of dividend payout. Results from this analysis are similar to the first one: firms with high overall CSR score are associated with high cash dividends to total assets ratio. 


\subsection{Individual components of CSR and dividend policy}

In line with the arguments developed in previous literature supporting that aggregating various dimensions of CSR may hide confounding effects among the individual dimensions of social responsibility (Galema et al., 2008; Bouslah et al., 2013); and in order to validate our second hypothesis, we extend the scope of our study by analyzing the relationship between individual components of social performance and dividend policy. To do so, we replicate the model in our main analysis (Table 6 Models 2 and 8) by substituting the overall CSR score with the following six attributes of CSR rating: corporate governance (CGOV_NET) in Models 1 and 7, employee Relations (EMPL_NET) in Models 2 and 8, diversity (DIV_NET) in Models 3 and 9, community (COM_NET) in Models 4 and 10, product characteristics (PRO_NET) in Models 5 and 11, and environment (ENV_NET) in Models 6 and 12. The results issued from these models are consistent with our second hypothesis and provide strong evidence for our main findings on aggregate CSR score. Thereby, five of the six individual components of CSR scores -namely, corporate governance (CGOV_NET), employee Relations (EMPL_NET), diversity (DIV_NET), community (COM_NET), and environment $(\text { ENV_NET })^{12}$ - are positively and statistically associated with dividend payout. This result suggests that most individual components of CSR do appear to matter for dividend policy and help increasing dividend payout. Thus, the higher is corporate governance and diversity scores, the more shareholders use the dividend policy to control the phenomenon of overinvestment in CSR; High community ${ }^{13}$ score may be due, inter alia, to high charitable giving practices which goes with high dividend payment in order to control for managers' donations strategy. The only component which has a negative effect on dividend policy is product characteristics score (PRO_NET) which loads negative and significant across the two Models (Models 5 and 11 Table 7). This negative relationship between product characteristics score and dividend payout is undoubtedly due to the components of this score. Indeed, the product characteristics strengths include research and development and innovation expenditures. These two elements require high investment and should be financed internally since firms avoid to reveal such information because of its strategic nature that could be used by the competitors (Bah and Dumontier, 2001). Firms favor then internal financing and, therefore,

\footnotetext{
${ }^{12}$ Environment score (ENV_NET) loads positive and significant only with the second measure of dividend payout (cash dividends to total assets in Model 12).

${ }^{13}$ Community is the KLD score which reflects the most firm donations.
} 
pay low dividends in order to keep larger amounts of cash at their disposal. This explains the negative relationship between product characteristics score and dividend payout in our study.

\subsection{CSR and the stability of dividend payout}

To test the stability of dividend payout, we split our sample into two sub-samples: high CSR firms with positive overall CSR score and low CSR firms with negative overall CSR score. We then use Lintner' model and estimate the speed of adjustment (SOA) and the target payout ratio (TPR) for both sub-samples. Table 8 shows the results from Lintner's model analysis. Models 1 and 2 present the main results and show that socially irresponsible firms adjust dividends quicker than do socially responsible firms. The SOA for low CSR firms is 0.57 which is higher than the SOA of 0.52 for high CSR firms. This indicates that dividend payout is more stable in high CSR firms than in low CSR firms. Regarding the TPR, there is a small difference between the two sub-samples of high and low CSR firms $(27.31 \%$ and $26.82 \%$ respectively). In Models 3 and 4, we use as dependent variable the changes in cash dividends from year $\mathrm{t}-2$ to year $\mathrm{t}$. The results provided by these two models do not differ from those found above. The SOA for low CSR firms is 0.63 which is higher than SOA of 0.54 for high CSR firms. This result also goes with high stability of dividends payment for high CSR firms. We finally consider this analysis using total cash dividends (the sum of cash common dividends and cash preferred dividends) the results are similar to those discussed previously.

In table 9, we extend the study of dividend payout stability to individual components of CSR. We split the sample into two sub-samples according to the score of the specific dimension studied. The results in table 9 provide strong support for those related to the overall CSR score. Firms which have low CSR scores measured separately by diversity, community, product characteristics, and environment tend to adjust their dividend payout quicker than do firms with high CSR in the same individual components ${ }^{14}$. The only dimension which goes against our expectation is corporate governance. Two potential explanations can be put forward to explain this result: first, firms with high corporate governance score use more their dividend policy to control for the agency problems related to over-investment in CSR. Second, firms with high corporate governance score tend to adjust their dividend policy depending on the cash in place. They first finance the investments which need to be financed internally and then pay dividends. These two elements are associated with less dividend

\footnotetext{
${ }^{14}$ The SOA in the sub-sample of CSR versus non CSR firms measured by employee relations score is not significant. We then do not compare the stability of dividend payout for These two sub-samples
} 
stability which may explain why firms with high corporate governance score adjust their dividends quicker than do firms with low corporate governance score.

6. Robustness tests

In order to examine the robustness of the link between CSR and dividend policy, we run additional analyses that assess the sensitivity of our results to alternative estimation methods, to alternative measures of dividend policy, to alternative measures of CSR scores, to additional controls, to potential endogeneity as well as an approach addressing the selfselection bias. The results of these additional tests are reported in the subsequent section; they all support our earlier evidence on the positive relationship between CSR and dividend policy.

\subsection{Alternative estimation methods ${ }^{15}$}

We test the robustness of our results to alternative estimation methods for the two measures of dividend payout used in the main analysis. Based on the panel nature of our data, and in order to dispel concerns about omitted variables and unobserved heterogeneity, we estimate firms fixed effects models (Models 1 and 6) and firms random effects models (models 2 and 7), respectively. In all these models, we continue to find that overall CSR score is positively related to dividend payout at the $1 \%$ significance level.

In Models 3-5 (Models 8-10 for our second measure of dividend payout), we use alternative methodologies to correct for the heteroscedasticity of the standards errors as well as for the autocorrelation of the residuals. In Model 3 (Model 8 for the second measure of dividend payout) we use the bootstrapping techniques using 100 random resample of the 22,389 firmyear observations observed in our initial sample. In Model 4 (Model 9 for the second measure of dividend payout), we use Fama and MacBeth (1973) procedure to account for crosssectional dependence. Finally, in Model 5 (Model 10 for the second measure of dividend payout), we present results for white standard errors. All the alternative models reported in Table 10 show positive and significant coefficients on overall CSR score (CSR_NET). They

\footnotetext{
${ }^{15}$ Models 1-5 in Table 10 report results for dividend payout measured as the cash dividends to net sales, while in Models 6-10 the payout ratio is measured by cash dividends to total assets. All these models lead to the same results and confirm that our main finding on a positive relationship between overall CSR score and dividend payout is robust for alternative estimation methods.
} 
provide support for our main evidence on the positive relationship between CSR and dividend payout, they also suggest that this relationship does not suffer from any model specification' problems.

\subsection{Alternative measures of dividend payout}

In table 11, we examine whether our main results are affected by any changes in the measure of dividend payout. We replicate our main model (Table 6 Model 2) after replacing the dependent variable with several other measures of dividend payout commonly used in the literature. In Models 1 and 2, we scaled cash common dividends by net income, and by firm market capitalization, respectively. In Model 3, our dependent variable is the natural logarithm of cash common dividends. In Models 4 and 5 we measure the dividend payout as the ratio of total cash dividends (the sum of cash common dividends and cash preferred dividends) to total assets, and to net sales, respectively. Model 6 uses the natural logarithm of total cash dividends (the sum of cash common dividends and cash preferred dividends) as dependent variable. Finally, in Model 7, we use a logistic regression: the dependent variable is a dummy that takes the value of 1 if the firm pays dividends and 0 otherwise. In each of the sixth first specifications, we find that the coefficient on overall CSR score (CSR_NET) loads positive and statistically significant at the 1\% level, while in Model 7 the coefficient on overall CSR score loads positive but significant at only a $10 \%$ level. These results reinforce our main evidence that firms with high social responsibility performance enjoy high dividend level.

\subsection{Alternative measures of CSR: controversial business issues}

In Table 12 we analyze the effects of involvement in six controversial business areas, namely, nuclear power, the military, tobacco, firearms, and gambling. We consider the number of concerns of each controversial area as our measure for the variable and we replicate the main models (Models 2 and 6 in Table 6) by including separately the controversial variables instead of the overall CSR score. We then use these controversial variables in Models 1 through 6 with a dependent variable equal to cash dividends to net sales, and in Models 7 through 12 with a dependent variable equal to cash dividends scaled by total assets. The results presented in Table 10 show that not all the controversial areas are relevant for dividend policy. We find that nuclear power (NUC_CON in Models 1 and 7), tobacco (TOB_CON in Models 4 and 10), firearms (FIR_CON in Models 5 and 11), gambling (GAM_CON in Models 6 and 12) do 
not affect dividend policy. Only the military and alcohol controversial areas are significantly associated with dividend payout. In Models 2 and 8 the coefficients on the military controversial areas (CSR_CONT) are negative and significant (at the 5\% level). In Models 3 and 9, alcohol number of concerns (CSR_CONT) loads negative and significant (at the 5\% level). This analysis suggests that firms involved in two controversial areas, namely, the military and alcohol pay less dividends. On one hand, this finding provides support for our main results suggesting that low CSR firms pay less dividends than high CSR firms. On the other hand, it may be due to high cost of external funding for firms involved in controversial areas as highlighted by Goss and Roberts (2011). Firms involved in controversial business areas might prefer to reduce their dividend payout and use their cash to finance internally their projects.

\subsection{Endogeneity}

In this last section of robustness tests, we perform an analysis to address a potential endogeneity bias. Three different approaches are then used: (1) additional control variables to ensure that our results are robust to potential omitted variables bias, (2) an instrumental variables estimation method consisting of two step regression to address endogeneity, (3) The propensity score matching analysis, and Heckman's (1979) two-stage self-selection model to address self-selection bias. These techniques are commonly employed and help to check that our inferences do not suffer from any endogeneity issues.

\subsubsection{Additional control variables}

Although we use the control variables affecting the dividend policy and suggested by prior literature, one may think that our evidence on a positive relationship between CSR and dividend payout is driven by potential omitted variables correlated with both CSR and the dividend payout. We add to our main models (Models 2 and 6 in Table 6) some additional less used variables suggested by prior literature to affect firm dividend policy and we run the models (Table 13). The results generally continue to provide strong support for the main finding. We start in Models 1 and 6 by introducing a tax variable (TAXE) which takes the value of 1 if the firm has a tax advantage from its previous years and 0 otherwise. The coefficient on tax (TAXE) loads negative and statistically significant at the $1 \%$ level: tax advantage is generally related to firm losses which is associated with low dividend payout. Our second additional variable is the ratio of research and development expenditures to total 
assets (R_D): in both Models 2 and 7 the coefficient on this variable is negative but insignificant. In Models 3 and 8, we consider the return on assets volatility (SROA) as an additional variable. The coefficient on SROA loads negative and statistically significant (at the $1 \%$ and $5 \%$ level or better) providing evidence that the more volatile return on assets, the lower the dividend payout. In Models 4 and 9, we consider firm age (AGE) measured by the number of years between the fiscal year and the first listing in the database. The coefficient on AGE is positive and significant at the $1 \%$ level suggesting that older firms pay more dividends which is consistent with the life cycle theory. We also consider the market to book ratio (MTB) as an additional variable to control for growth opportunities (Models 5 and 11). The coefficient on MTB loads positive and significant (at $1 \%$ level). We finally include all the previous variables in one model (Models 6 and 12); the results concerning the additional variables remain essentially unchanged. More important for our purposes: controlling for additional firm characteristics does not affect our inference on the role of CSR in dividend payout: all the models in Table 13 show positive and significant coefficients on CSR_NET (at the $1 \%$ level).

\subsubsection{The instrumental variables approach}

The instrumental variables approach is commonly used in studies on CSR; it helps to address issues related to invisible variables affecting the relationship between CSR and dividend payout. The instrumental estimation method consists of two step regression: in the first one, we regress the overall CSR score on the instruments and on explanatory variables used in the baseline model (Model 2 Table 6), in the second step regression, the predicted value of overall CSR score substitutes the overall CSR score (CSR_NET) in the main model (Model 2 in Table 6). We follow El ghoul, et al. (2011) by considering the industry-year average of the overall CSR score (CSR_IND), and Attig et al. (2013) by considering the initial value of the firm' overall CSR score (CSR_INI). These two instruments are likely to be exogenous to the contemporaneous overall CSR score. In table 14, we report the results of the first-stage regressions (Models 1 and, 3), and the second stage regression (Models 2 and 4). The first stage regressions show that larger firms, with high cash holdings, and high profitability are those which enjoy high overall CSR score. Furthermore, the two instrumental variables used in this first stage regression, namely, the industry year average of CSR (CSR_IND), and the initial value of the CSR score (CSR_INI) are positive and affect significantly the overall CSR score. In the second stage regression, we find that the effect of CSR on firms' dividend payout 
(Models 2 and 4) remains significantly positive (at the 1\% level), which supports our earlier findings and suggests that endogeneity does not affect our results.

\subsubsection{Propensity score matching analysis}

The propensity score matching (PSM) analysis was firstly developed by Rosenbaum and Rubin (1983) in order to confront self-selection bias. PSM consists of matching observations based on the probability of increasing their overall CSR score. More precisely, PSM estimates the effects of overall CSR score on dividend policy by comparing the dividend payout of firms which increase their overall CSR score by investing ethically (treated group), with the dividend payout of firms that have similar probability to increase their overall CSR score and be socially responsible but for which no such event takes place (control group). In other words, we match a high CSR firm with a low CSR firm sharing similar characteristics as reported by their propensity scores, we then calculate the average difference in payout ratio between the high and the low CSR groups. To implement a PSM analysis, we first start by constructing a CSR dummy variable that takes 1 if the firm has a positive overall CSR score and 0 otherwise. We then estimate a probit model where the dependent variable is the dummy variable created above, and the independent variables are the control variables used in the main analysis, the two instruments (CSR_IND and CSR_INI) used in the previous section, time and industry fixed effects. We use the score estimated to match each observation with high CSR score to an observation with low CSR score. To do so, we employ four different matching techniques: one-to-one matching without replacement, one-to-one matching with replacement, the nearest-neighbor with $n=2$ and the nearest-neighbor with $n=3$. We finally use two analysis to study the effect of CSR on dividend policy: in the first analysis, we compare the average of the dividend payout ratio between high CSR firms and their matched neighbors. In the second analysis, we use the propensity score matched samples an re-run linear models as those estimated in the main analysis (Models 2 and 8 Table 6).

The results related to both analyses are reported in Table 15. In the univariate tests, we find strong evidence that high CSR firms pay more dividends than low CSR firms. The average difference between high CSR firms' dividend payout ratio and the mean dividend payout ratio of their matched neighbors with low CSR score ranges between $7.20 \%$ for the one-to-one matching with replacement and $35.46 \%$ for the one-to-one matching without replacement ( $8.85 \%$ and $39.39 \%$, respectively, for the second ratio of dividend payout). This difference is 
statistically significant at the $5 \%$ level or better. Turning to the regression analysis, in all matched samples (Models 1 to 4 and 5 to 8), we continue to find a positive and statistically significant coefficient on overall CSR score, indicating that high CSR firms are associated with high dividend payout.

\subsubsection{Heckman's (1979) two-stage self-selection model}

We address the self-selection bias using Heckman's (1979) two-stage self-selection model. The main objective of this analysis is to control for self-selection bias induced by firms choosing to increase their level of social performance. In the first step, we use a probit model to regress a dummy variable that takes the value of 1 if the firm has a positive overall CSR score, and 0 otherwise, on all control variables from our main specification (Model 2 in Table 6) and on the instrumental variables used in the previous section (CSR_IND, and CSR_INI). In the second stage regression, dividend payout variables are the dependent variables, overall CSR score is the interest variable, the control variables are those used in the main specification, and we include the self-selection parameter (measured as the inverse Mills' ratio) estimated from the first stage.

The results are reported in Table 16: even after controlling for the self-selection bias using the two-step estimation model, this analysis continues to suggest that higher overall CSR score is associated with higher dividend payout.

\section{Conclusion}

In this paper, we examine how dividend policy can play a role in controlling the problems of overinvestment in CSR due to agency issues between insiders and outsiders in socially responsible firms. We also explore whether the wealth created in firms with high social performance is distributed in a way respecting and satisfying the interest of all shareholders.

Using a large sample of US firms of 3,040 unique firms and 22,389 firm-year observations between 1991 and 2012, and after controlling for determinants of dividend policy suggested in the literature as well as firm and industry fixed effects, we find that high CSR firms pay more dividends than low CSR firms. This result provides strong evidence for our first hypothesis and suggests that CSR firms may use the dividend policy to manage their agency problems. This result also shows that CSR firms are not only socially responsible in their wealth creation process but they are more likely to be in the distribution of the wealth created. 
Furthermore, five of the six dimensions used in the analysis are also associated with high dividend payout, namely, corporate governance, community, diversity, employee relations, and environment. The only dimension associated with low dividend payout is product characteristics. This is more likely due to the integration of research and development and innovation expenditures in the calculation of this score. Additionally, by analyzing the stability of dividend payout, we find that socially irresponsible firms adjust dividends quicker than do socially responsible firms; this provides support for our third hypothesis claiming that dividend payout is more stable in high CSR firms than in low CSR firms. We finally show that firms involved in two controversial activities, namely, military and alcohol are associated with low dividend payout. Firms involved in these two controversial areas might face high external funding cost as highlighted by Goss and Roberts (2011). They may prefer to pay low dividends in order to finance their activities internally.

Our findings are robust to a battery of sensitivity tests, including alternative assumptions and model specifications, alternative measures of dividend payout, additional control variables, instrumental variables, the propensity score matching approach, and the Heckman Selection Model to address endogeneity and selection bias issues.

This paper examines dividend policy for firms covered by KLD and located in U.S. In order to generalize the study' main findings, future researches should extend the framework of the relationship between CSR and dividend policy by considering other countries/regions and different social performance ratings. 
Appendix A. Qualitative issue areas and controversial business issues definitions.

Panel A. Qualitative issue areas

We consider six qualitative issue areas from KLD: community, diversity, employee relations, environment, product characteristics and corporate governance. Each area has several strengths and concerns as illustrated below. We calculate a score for each area equal to the number of strengths minus the number of concerns. The overall CSR is equal to the sum of all areas' scores.

\begin{tabular}{|c|c|c|}
\hline Dimension & Strengths & Concerns \\
\hline Community & $\begin{array}{l}\text {-Charitable Giving } \\
\text {-Innovative Giving } \\
\text {-Non-US Charitable Giving } \\
\text {-Support for Housing } \\
\text {-Support for Education } \\
\text {-Indigenous Peoples Relations } \\
\text {-Volunteer Programs } \\
\text {-Other Strength }\end{array}$ & $\begin{array}{l}\text {-Investment Controversies } \\
\text {-Negative Economic Impact } \\
\text {-Indigenous Peoples relations } \\
\text {-Tax Disputes } \\
\text {-Other Concern }\end{array}$ \\
\hline Diversity & $\begin{array}{l}\text {-CEO's identity - Promotion } \\
\text {-Board of Directors } \\
\text {-Women and Minority Contracting } \\
\text {-Employment of the Disabled } \\
\text {-Gay and Lesbian Policies- Other } \\
\text { strength }\end{array}$ & $\begin{array}{l}\text {-Controversies (e.g. fines) } \\
\text {-Non-Representation } \\
\text {-Other Concern }\end{array}$ \\
\hline Employee Relations & $\begin{array}{l}\text {-Union Relations } \\
\text {-No-Layoff Policy } \\
\text {-Cash Profit Sharing } \\
\text {-Employee Involvement } \\
\text {-Retirement Benefits Strength } \\
\text {-Health and Safety Strength } \\
\text {-Other Strength }\end{array}$ & $\begin{array}{l}\text {-Union Relations } \\
\text {-Health and Safety Concern } \\
\text {-Workforce Reductions } \\
\text {-Retirement Benefits Concern } \\
\text {-Other Concern }\end{array}$ \\
\hline Environment & $\begin{array}{l}\text {-Benefical Products and Services } \\
\text {-Pollution Prevention } \\
\text {-Recycling } \\
\text {-Clean Energy } \\
\text {-Communications } \\
\text {-Property, Plant, and Equipement } \\
\text {-Management Systems } \\
\text {-Other Strength }\end{array}$ & $\begin{array}{l}\text {-Hazardous Waste } \\
\text {-Regulatory Problems } \\
\text {-Ozone Depleting Chemicals } \\
\text {-Substantial Emissions } \\
\text {-Agricultural Chemicals } \\
\text {-Climate Change } \\
\text {-Other Concern }\end{array}$ \\
\hline Product & $\begin{array}{l}\text {-Quality } \\
\text {-R\&D/Innovation } \\
\text {-Benefits to Economically } \\
\text { Disadvantaged } \\
\text {-Other Strength }\end{array}$ & $\begin{array}{l}\text {-Product Safety } \\
\text {-Marketing/Contracting Concern } \\
\text {-Antitrust } \\
\text {-Other Concern }\end{array}$ \\
\hline Corporate Governance & $\begin{array}{l}\text {-Limited Compensation } \\
\text {-Ownership Strength } \\
\text {-Transparency Strength } \\
\text {-Political Accountability Strength } \\
\text {-Other Strength }\end{array}$ & $\begin{array}{l}\text {-High Compensation } \\
\text {-Ownership Concern } \\
\text {-Accounting Concern } \\
\text {-Political Accountability Concern } \\
\text {-Transparency Concern } \\
\text {-Other concern }\end{array}$ \\
\hline
\end{tabular}


Panel B. Controversial Business Issues

We consider six controversial business issues: Alcohol, Gambling, Tobacco, Firearms, Military, and Nuclear Power. We then use the number of concerns in each issue as our measure of each controversial business issue.

\begin{tabular}{|c|c|}
\hline Dimension & Concerns \\
\hline \multirow[t]{8}{*}{ Alcohol } & Licensing \\
\hline & Manufacturers \\
\hline & Manufacturers of products necessary for production of alcoholic \\
\hline & beverages \\
\hline & Retailers \\
\hline & Ownership by an alcohol company \\
\hline & Ownership of an alcohol company \\
\hline & Alcohol other concern \\
\hline \multirow[t]{7}{*}{ Gambling } & Licensing \\
\hline & Manufacturers \\
\hline & Owners and operators \\
\hline & Supporting products or services \\
\hline & Ownership by a gambling company \\
\hline & Ownership of a gambling company \\
\hline & Gambling other concern \\
\hline \multirow[t]{8}{*}{ Tobacco } & Licensing \\
\hline & Manufacturers \\
\hline & Manufacturers of products necessary for production of tobacco \\
\hline & 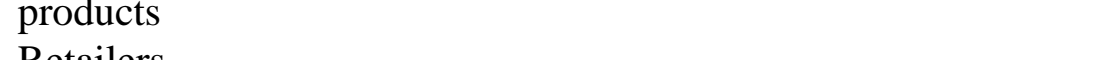 \\
\hline & Retailers \\
\hline & Ownership by a tobacco company \\
\hline & Ownership of a tobacco company \\
\hline & Tobacco other concern \\
\hline \multirow[t]{4}{*}{ Firearms } & Manufacturers \\
\hline & Retailers \\
\hline & Ownership by a firearms company \\
\hline & Ownership of a firearms company \\
\hline \multirow[t]{7}{*}{ Military } & Manufacturers of weapons or weapons systems \\
\hline & Manufacturers of components for weapons or weapons systems \\
\hline & Ownership by a military company \\
\hline & Ownership of a military company \\
\hline & Minor weapons contracting involvement \\
\hline & Major weapons-related supplier \\
\hline & Military other concern \\
\hline \multirow[t]{9}{*}{ Nuclear } & Power Construction \& design of nuclear power plants \\
\hline & Nuclear power fuel and key parts \\
\hline & Nuclear power service provider \\
\hline & Ownership of nuclear power plants \\
\hline & Ownership by a nuclear power company \\
\hline & Ownership of a nuclear power company \\
\hline & Design \\
\hline & Fuel cycle/key parts \\
\hline & Nuclear power other concern \\
\hline
\end{tabular}




\begin{tabular}{|c|c|c|}
\hline Variables & Definition & Source \\
\hline \multicolumn{3}{|c|}{ Panel A. Dependent variables } \\
\hline DIV_SALES & The ratio of cash common dividends to net sales & COMPUSTAT data \\
\hline DIV_ASSETS & The ratio of cash common dividends to total assets & As above \\
\hline VAR & It measures the changes in cash common dividends from year $\mathrm{t}-1$ to $\mathrm{t}$ & As above \\
\hline \multicolumn{3}{|c|}{ Panel B. CSR variables } \\
\hline CGOV_NET & $\begin{array}{l}\text { The corporate governance score equals to the number of strengths minus } \\
\text { the number of concerns in the corporate governance qualitative issues area }\end{array}$ & KLD STATS data \\
\hline EMPL_NET & $\begin{array}{l}\text { The employee relations score equals to the number of strengths minus } \\
\text { the number of concerns in the employee relations qualitative issues area }\end{array}$ & As above \\
\hline DIV_NET & $\begin{array}{l}\text { The diversity score equals the number of strengths minus the } \\
\text { number of concerns in the riversity qualitative issues area. }\end{array}$ & As above \\
\hline COM_NET & $\begin{array}{l}\text { The community score equals the number of strengths minus the } \\
\text { number of concerns in the community qualitative issues area. }\end{array}$ & As above \\
\hline PRO_NET & $\begin{array}{l}\text { The product score equals the number of strengths minus the number } \\
\text { of concerns in the roduct qualitative issues area. }\end{array}$ & As above \\
\hline ENV_NET & $\begin{array}{l}\text { The environment score equals the number of strengths minus the } \\
\text { number of concerns in the environment qualitative issues area. }\end{array}$ & As above \\
\hline CSR_NET & $\begin{array}{l}\text { The CSR score equals the sum of the community, diversity, employee, environment, } \\
\text { Product characteristics, and corporate governance qualitative issues areas score }\end{array}$ & As above \\
\hline NUC_NET & The number of concerns in the nuclear controversial business issue & As above \\
\hline MIL_NET & The number of concerns in the military controversial business issue & As above \\
\hline ALC_NET & The number of concerns in the alcohol controversial business issue & As above \\
\hline TOB_NET & The number of concerns in the tobacco controversial business issue & As above \\
\hline FIR_NET & The number of concerns in the firearms controversial business issue & As above \\
\hline GAM_NET & The number of concerns in the gambling controversial business issue & As above \\
\hline \multicolumn{3}{|c|}{ Panel C. Control Variables } \\
\hline SIZE & Natural logarithm of dollar value of total book value assets & COMPUSTAT data \\
\hline $\mathrm{CASH}$ & Cash and short-term investments scaled by book value of total assets & As above \\
\hline
\end{tabular}


ROA

RE_TE

$\mathrm{D}_{\mathrm{t}-1}$

Net income scaled by book value of total assets

As above

Retained earnings scaled by common equity

Lag of common cash dividend (common cash dividend of year t-1)

As above

As above

Earnings before interests, but after taxes

As above

\section{Panel D. Additional variables used in robustness tests}

\section{DIV_NI \\ DIV_CAP \\ TDIV_SALES \\ LOG_DIV \\ LOG_TDIV \\ DUMMY \\ TAXE \\ R_D}

TDIV_ASSETS

SROA

AGE

MTB
The ratio of cash common dividends to net income

The ratio of cash common dividends to firm market capitalization

The ratio of total cash dividends (the sum of cash common dividends and cash preferred dividends) to total assets

The ratio of total cash dividends (the sum of cash common dividends and cash preferred dividends) to net sales

The logarithm of common cash dividends

The logarithm of total cash dividends (the sum of cash common dividends and cash preferred dividends)

Dummy variable set to 1 if the firm pays dividends, and 0 otherwise

Dummy variable that takes one if the firm has a tax advantage, and 0 otherwise

Research and development ratio, defined as research and development expenditures to total assets.

Asset volatility defined as the standard deviation of ROA over the previous five years.

Number of years between fiscal year and the first listing in the database

Market to Book ratio. The market value is defined as the book value of total assets minus the book value of equity plus the market value of equity. The book value is equal to total assets.

\section{Panel E. Instrumental variables}

\begin{tabular}{lll}
\hline CSR_IND & The industry-year average of overall CSR score & KLD STATS data \\
CSR_INI & the firm-level initial value of overall CSR score & KLD STATS data \\
\hline
\end{tabular}




\section{References}

Attig, N., 2011. Intangible assets, organizational capital and corporate social responsibility: Evidence from U.S. manufacturing firms. Working paper, Saint Mary’s University.

Attig, N., Boubakri, N., El Ghoul, S., Guedhami, O., 2013. International diversification and corporate social responsibility. Working paper, Saint Mary’s University.

Attig, N., El Ghoul, S., Guedhami, O., Suh, J., 2013. Corporate social responsibility and credit ratings. Journal of Business Ethics 117, 679-694.

Aivizian, V., Booth, L., Cleary, S., 2003. Dividend policy and the organization of capital markets. Journal of Multinational Financial Management, 13(2), 101-121.

Bae, K., Kang, J., Wang, J., 2011. Employee treatment and firm leverage: a test of the stakeholder theory of capital structure. Journal of Financial Economics 100, 130-153.

Bah, R., Dumontier, P., 2001. R\&D Intensity and Corporate Financial Policy: Some International Evidence. Journal Of Business Finance \& Accounting, 28(5/6)

Barnea, A., Rubin. A., 2010. Corporate social responsibility as a conflict between shareholders. Journal of Business Ethics 97, 71-86.

Benartzi, S., Michaely, R., and Thaler, R. H., 1997. Do changes in dividends signal the future or the past? Journal of Finance, 52 (3), 1007-1034.

Berk, J. B., Stanton, R., Zechner, J., 2010. Human capital, bankruptcy, and capital structure. Journal of Finance 65(3), 891-926.

Bhattacharya, S., 1979. Imperfect information, dividend policy, and the "bird in the hand" fallacy. Bell Journal of Economics, 10(1), 259-270.

Bouslah, K., Kryzanowski, L., M'Zali, B., 2013. The impact of the dimensions of social performance on firm risk. Journal of Banking and Finance 37, 1258-1273.

Brav, A., Graham, J., Harvey, C., and Michaely, R., 2005, Payout Policy in the 21 Century. Journal of Financial Economics 77, 483-527 
Brockman, P., Unlu, E., 2009. Dividend Policy, Creditor Rights, and the Agency Costs of Debt. Journal of Financial Economics 92, 276-299.

Brown, W. O., Helland, E., Smith, J.K., 2006. Corporate philanthropic practices. Journal of Corporate Finance, 12 (5), 855-877.

Chatterji, A. K., Levine, D. I., Toffel, M. W., 2009. How well do social ratings actually measure corporate social responsibility? Journal of Economics and Management Strategy 18, 125-169.

Chay, J.B., Suh, J., 2009. Payout policy and cash-flow uncertainty. Journal of Financial Economics, 93 (1), 88-107.

Denis, D. J., Osobov, I., 2008. Why do firms pay dividends? International evidence on the determinants of dividend policy. Journal of Financial Economics, 89 (1), 62-82.

Deshmukh, S., Goel, A., Howe, K., 2013. CEO overconfidence and dividend policy. Journal of Financial Intermediation 22, 440-463.

Dhaliwal, D., Li, O., Tsang, A., Yang, G., 2011. Voluntary nonfinancial disclosure and the cost of equity capital: the initiation of corporate social responsibility reporting. The Accounting Review, 86 (1), 59-100.

Easterbrook, F., 1984. Two agency cost explanations of dividends. American Economic Review 74, 650-659.

El Ghoul, S., Guedhami, O., Kwok, C., Mishra, D., 2011. Does corporate social responsibility affect the cost of capital? Journal of Banking and Finance 35, 2388-2406.

Faccio, M., Lang, L. H. P., \& Young, L. 2001. Dividends and expropriation. American Economic Review, 91(1), 54-78.

Fama, E. F., Babiak, H., 1968. Dividend policy: an empirical analysis, Journal of the American Statistical Association 63, 1132-1161.

Fama, E. F., Macbeth., J.D., 1973. Risk, Return, and Equilibrium: Empirical Tests. The Journal of Political Economy, 81 (3), 607-636. 
Fama, E. F., French, K. R., 2001. Disappearing dividends: Changing firm characteristics or lower propensity to pay? Journal of Financial Economics 60, 3-43.

Fenn, G., Liang, N., 2001. Corporate Payout Policy and Managerial Stock Incentives. Journal of Financial Economics 60, 45-72.

Fombrun, C., Shanely, M., 1990. What's in a Name? Reputation Building and Corporate Strategy, Academy of Management Journal 33, 233-258.

Freeman, R. E., 1984. Strategic management: A stakeholder approach. Boston: Pitman/Ballinger.

Galema, R., Plantinga, A., Scholtens, B., 2008. The stocks at stake: return and risk in socially responsible investment. Journal of Banking and Finance 32, 2646-2654.

Gilson, S. C., John, K., and Lang, L. H. P., 1990. An empirical study of private reorganization of firms in default. Journal of Financial Economics 27, 315-353.

Girerd-Potin, I., Jimenez-Garces, S., Louvet, P., 2011. The link between Social Rating and Financial Capital Structure. Finance 32, 9-52.

Gordon, M. J., 1963. Optimal investment and financing policy. Journal of Finance 18, 264272.

Goss, A., Roberts, G. S., 2011. The impact of corporate social responsibility on the cost of bank loans. Journal of Banking and Finance 35, 1794-1810.

Hakansson N., 1982. To Pay or Not to Pay Dividends. Journal of Finance, 37 (2), 415-428.

He, T. T., Li, W. X. B., Tang, G. Y. N., 2012. Dividends behavior in state - versus familycontrolled firms: Evidence from Hong Kong. Journal of Business Ethics 110, 97-112.

Hillman, A. J., Keim, J. D., 2001. Shareholder value, stakeholder management, and social issues: What's the bottom line? Strategic Management Journal 22, 125-139.

Hong, H., Kacperczyk, M., 2009. The price of sin: the effects of social norms on markets. Journal of Financial Economics 93, 15-36. 
Jensen M., 1986. Agency Costs of free-cash flow, corporate finance and the Market for Takeovers. American Economic Review 76, 323-329.

Jensen, M. C. and Meckling, W.H., 1976.Theory of the Firm: Managerial Behavior, Agency Costs and Ownership Structure. Journal of Financial Economics , 3 (4), 305-360.

Jo, H., Na, H., 2012. Does CSR reduce firm risk? Evidence from controversial industry sectors. Journal of Business Ethics, 110 (4), 441-457.

John K., Williams, J., 1985. Dividends, Dilution and Taxes. Journal of Finance 40, 10531070.

Kalay A, 1980. Signalilng Information Content, and the reluctance to cut Dividends. Journal of Financial and Quantitative Analysis 15, 855-869.

La Porta, R., Lopez-de-Silanes, F., Shleifer, A., Vishny, R. W., 2000. Agency problems and dividend policies around the world. Journal of Finance, 55(1), 1-33.

Lewellen W. et Emery., "On the Matter of Parity Among Financial Obligations", Journal of Finance 36, Jan 1981, pp 97-111.

Lintner, J., 1956. Distribution of Incomes of Corporations Among Dividends, Retained Earnings, and Taxes. American Economic Review, 46(2), 97-113.

Lintner, J., 1962. Dividends, earnings, leverage, stock prices and supply of capital to corporations. The Review of Economics and Statistics 64, 243-269.

Margolis, J. D., Elfenbein, H. A., Walsh, J. P., 2007. Does it pay to be good? A meta analysis and redirection of research on the relationship between corporate social and financial performance. Working paper, Harvard University.

Margolis, J. D., Walsh, J. P., 2003. Misery companies: Rethinking social initiatives by business. Administrative Science Quarterly, 48(2), 268-305.

McGuire, J., A. Sundgren, and T. Schneeweis, 1988, Corporate Social Responsibility and Firm Financial Performance. Academy of Management Journal 31, 854-872. 
Miller, M., and Modigliani, F. 1961. Dividend policy, growth and the valuation of shares. Journal of Business, 34(4), 411-433.

Miller, M. H., and Rock, K., 1985. Dividend policy under asymmetric information. Journal of Finance 40, 1031-1051.

Mitton, T., 2004. Corporate Governance and Dividend Policy in Emerging Markets. Emerging Markets Review 5, 409-426.

Mueller, D. C., 1972. A Life Cycle Theory of the Firm. Journal of Industrial Economics, 20 (3), 199-2019.

Ofer, A. R., Siegel, D. R., 1987. Corporate financial policy, information, and market expectations: An empirical investigation of dividends. Journal of Finance, 42(5), 889-911.

Petersen, M. A., 2009. Estimating Standard Errors in Finance Panel Data Sets: Comparing Approaches. Review of Financial Studies, 22, 435-480.

Robinson, J., 2006. Dividend policy among publicly listed firms in Barbados. Journal of Eastern Caribbean Studies, 31, 1-36.

Robinson, M., A. Kleffner, and S. Bertels, 2011, Signaling sustainability leadership: empirical evidence of the value of DJSI membership. Journal of Business Ethics, 101 (3), 493-505.

Rosenbaum, P. R., Rubin, D. B., 1983. The Central Role of the Propensity Score in Observational Studies for Causal Effects. Biometrika, 70 (1), 41-55.

Ross S., 1977. The Determination of Financial Structure: The Incentive Signalling Approach. Bell Journal of Economics 8, 23-40.

Servaes, H., Tamayo, A., 2013. The Impact of Corporate Social Responsibility on Firm Value: The Role of Customer Awareness. Management Science 59, 1045-1061.

Shao, L., Chuck, C.Y. K., Guedhami, O., 2010. National culture and dividend policy. Journal of International Business Studies 41, 1391-1414.

Sharfman, M., 1996. The construct validity of the Kinder, Lydenberg \& Domini social performance rating data. Journal of Business ethics 15, 287-296. 
Shevlin, T., 1982. Australian corporate dividend policy: empirical evidence. Accounting and Finance, $22(1), 1-22$.

Smith Jr., C. W., and Watts, R., L., 1992. The Investment Opportunity Set and Corporate Financing, Dividend, and Compensation Policies. Journal of Financial Economics 32 , 263292.

Von Eije, H., Megginson, W. L., 2008. Dividends and share repurchases in the European Union. Journal of Financial Economics 89, 347-374.

Waddock, S. A., 2003. Myths and realities of social investing. Organization and Environment, $16,369-380$.

Waddock, S. A., Graves, S. B., 1997. The Corporate Social Performance-Financial Performance Link. Strategic Management Journal 18, 303-319.

Wood, D. J., 1995. The Fortune database as a CSP measure. Business and society 34, $197-$ 198. 
Table 1. Sample breakdown by year and industry

\begin{tabular}{|c|c|c|c|c|c|c|}
\hline Year & $\mathrm{N}$ & $\%$ & Year & & $\mathrm{N}$ & $\%$ \\
\hline 1991 & 263 & 1.15 & 2008 & & 1,923 & 8.42 \\
\hline 1992 & 268 & 1.17 & 2009 & & 1,992 & 8.72 \\
\hline 1993 & 271 & 1.19 & 2010 & & 2,039 & 8.93 \\
\hline 1994 & 272 & 1.19 & 2011 & & 1,960 & 8.58 \\
\hline 1995 & 274 & 1.20 & 2012 & & 1,965 & 8.60 \\
\hline 1996 & 288 & 1.26 & Total & & 22,839 & 100.00 \\
\hline 1997 & 305 & 1.34 & & & & \\
\hline 1998 & 308 & 1.35 & Industry & Two-digit SIC & $\mathrm{N}$ & $\%$ \\
\hline 1999 & 327 & 1.43 & Agriculture, forestry and fisheries & $<10$ & 73 & 0.32 \\
\hline 2000 & 351 & 1.54 & Mineral industries & $10-14$ & 1,326 & 5.81 \\
\hline 2001 & 622 & 2.72 & Construction industries & $15-17$ & 342 & 1.50 \\
\hline 2002 & 627 & 2.75 & Manufacturing & $20-39$ & 12,091 & 52.94 \\
\hline 2003 & 1,624 & 7.11 & Transportation communications & $40-48$ & 1,685 & 7.38 \\
\hline 2004 & 1,762 & 7.71 & Wholesale trade & $50-51$ & 765 & 3.35 \\
\hline 2005 & 1,757 & 7.69 & Retail trade & $52-59$ & 2,113 & 9.25 \\
\hline 2006 & 1,795 & 7.86 & Service industries & $>70$ & 4,444 & 19.46 \\
\hline 2007 & 1,846 & 8.08 & Total & & 22,839 & 100.00 \\
\hline
\end{tabular}

This table presents calendar year and the industry (according to the two-digit Standard Industrial Classification) distributions for the 22839 firm-year observations comprising the sample between 1991 and 2012. Financial firms (SIC codes 6000-6999) and utility firms (sic between 4900 and 4999 ) are excluded. 
Table 2. Descriptive statistics for corporate social responsibility data

\begin{tabular}{|c|c|c|c|c|c|c|c|c|}
\hline & Mean & Min & Q1 & Median & Q3 & Max & Std & $\mathrm{N}$ \\
\hline \multicolumn{9}{|c|}{ Panel A. Descriptive statistics for corporate social responsibility scores } \\
\hline CSR_NET & -0.35 & -9.00 & -2.00 & -1.00 & 1.00 & 18.00 & 2.46 & 22,839 \\
\hline CGOVV_NET & -0.27 & -4.00 & -1.00 & 0.00 & 0.00 & 3.00 & 0.71 & 22,839 \\
\hline EMPL_NET & -0.09 & -4.00 & -1.00 & 0.00 & 0.00 & 7.00 & 0.93 & 22,839 \\
\hline DIV_NET & 0.03 & -3.00 & -1.00 & 0.00 & 1.00 & 7.00 & 1.33 & 22,839 \\
\hline COM_NET & 0.10 & -2.00 & 0.00 & 0.00 & 0.00 & 4.00 & 0.51 & 22,839 \\
\hline PRO_NET & -0.12 & -4.00 & 0.00 & 0.00 & 0.00 & 2.00 & 0.59 & 22,839 \\
\hline \multirow[t]{2}{*}{ ENV_NET } & -0.01 & -5.00 & 0.00 & 0.00 & 0.00 & 5.00 & 0.78 & 22,839 \\
\hline & Mean & Min & Q1 & Median & Q3 & Max & Std & $\mathrm{N}$ \\
\hline \multicolumn{9}{|c|}{ Panel B. Descriptive statistics by year for overall corporate social responsibility score } \\
\hline 1991 & 0.43 & -6.00 & 0.00 & 0.00 & 2.00 & 7.00 & 2.08 & 263 \\
\hline 1992 & 0.41 & -7.00 & -1.00 & 0.00 & 2.00 & 8.00 & 2.31 & 268 \\
\hline 1993 & 0.21 & -8.00 & -1.00 & 0.00 & 2.00 & 9.00 & 2.57 & 271 \\
\hline 1994 & 0.26 & -8.00 & -1.00 & 0.00 & 2.00 & 10.00 & 2.70 & 272 \\
\hline 1995 & 0.53 & -7.00 & -1.00 & 0.00 & 2.00 & 13.00 & 2.71 & 274 \\
\hline 1996 & 0.95 & -8.00 & -1.00 & 1.00 & 2.00 & 11.00 & 2.45 & 288 \\
\hline 1997 & 0.66 & -7.00 & -1.00 & 1.00 & 2.00 & 11.00 & 2.58 & 305 \\
\hline 1998 & 0.56 & -8.00 & -1.00 & 0.00 & 2.00 & 10.00 & 2.74 & 308 \\
\hline 1999 & 0.54 & -7.00 & -1.00 & 1.00 & 2.00 & 12.00 & 2.81 & 327 \\
\hline 2000 & 0.56 & -8.00 & -1.00 & 1.00 & 2.00 & 11.00 & 2.66 & 351 \\
\hline 2001 & 0.21 & -9.00 & -1.00 & 0.00 & 1.00 & 9.00 & 2.18 & 622 \\
\hline 2002 & 0.09 & -8.00 & -1.00 & 0.00 & 1.00 & 8.00 & 2.28 & 627 \\
\hline 2003 & -0.21 & -9.00 & -1.00 & 0.00 & 1.00 & 8.00 & 1.71 & 1,624 \\
\hline 2004 & -0.47 & -8.00 & -2.00 & -1.00 & 0.00 & 11.00 & 1.87 & 1,762 \\
\hline 2005 & -0.51 & -8.00 & -2.00 & -1.00 & 0.00 & 12.00 & 2.07 & 1,757 \\
\hline 2006 & -0.68 & -9.00 & -2.00 & -1.00 & 0.00 & 15.00 & 2.22 & 1,795 \\
\hline 2007 & -0.68 & -9.00 & -2.00 & -1.00 & 0.00 & 15.00 & 2.32 & 1,846 \\
\hline 2008 & -0.68 & -9.00 & -2.00 & -1.00 & 0.00 & 14.00 & 2.32 & 1,923 \\
\hline 2009 & -0.67 & -9.00 & -2.00 & -1.00 & 0.00 & 14.00 & 2.29 & 1,992 \\
\hline
\end{tabular}


This table shows descriptive statistics for corporate social responsibility data for the 22,389 firm-year observations between 1991 and 2012 . Panel A provides the mean, minimum, first quartile, median, third quartile, maximum, standard deviation, and the number of observations for overall corporate social responsibility score (CSR_NET), corporate governance score (CGOV_NET), employee relations score (EMPL_NET), diversity score (DIV_NET), community score (COM_NET), product characteristics score (PRO_NET), and environmental performance score (ENV_NET). Panel B provides the mean, minimum, first quartile, median, third quartile, maximum, standard deviation, and the number of observations for overall corporate social responsibility score per year. Appendix A\&B outline the definitions for all corporate social responsibility scores as well as the way we calculate overall corporate social responsibility score. 
Table 3. Descriptive statistics for regression variables.

\begin{tabular}{|c|c|c|c|c|c|c|c|c|}
\hline & Mean & Min & Q1 & Median & Q3 & Max & Std & $\mathrm{N}$ \\
\hline \multirow[t]{2}{*}{ DIV_ASSETS \% } & 0.97 & 0.00 & 0.00 & 0.00 & 1.51 & 5.24 & 1.51 & 22,839 \\
\hline & Mean & Min & Q1 & Median & Q3 & Max & Std & $\mathrm{N}$ \\
\hline \multicolumn{9}{|c|}{ Panel B. Descriptive statistics for control variables } \\
\hline SIZE & 7.08 & 4.61 & 5.87 & 6.98 & 8.19 & 10.02 & 1.52 & 22,839 \\
\hline CASH & 0.19 & 0.01 & 0.04 & 0.11 & 0.28 & 0.65 & 0.19 & 22,839 \\
\hline DEBT & 0.20 & 0.00 & 0.02 & 0.18 & 0.32 & 0.60 & 0.18 & 22,839 \\
\hline ROA & 0.03 & -0.26 & 0.007 & 0.05 & 0.09 & 0.18 & 0.10 & 22,839 \\
\hline \multirow[t]{2}{*}{ RE_TE } & 0.15 & -3.73 & -0.04 & 0.50 & 0.86 & 1.74 & 1.25 & 22,839 \\
\hline & Mean & Min & Q1 & Median & Q3 & Max & Std & $\mathrm{N}$ \\
\hline \multicolumn{9}{|c|}{ Panel C. Descriptive statistics for variables related to robustness tests } \\
\hline MTB & 2.04 & 0.35 & 1.25 & 1.66 & 2.44 & 5.10 & 1.12 & 22,839 \\
\hline
\end{tabular}

This table presents descriptive statistics for the regression variables for the 22,839 firm-year observations between 1991 and 2012 . Financial firms (SIC codes 6000-6999) and utility firms (sic between 4900 and 4999) are excluded. Panel A provides the mean, minimum, first quartile, median, third quartile, maximum, standard deviation, and the number of observations for the dependent variables. Panel B presents the mean, minimum, first quartile, median, third quartile, maximum, standard deviation, and the number of observations for the control variables. Panel C reports the mean, minimum, first quartile, median, third quartile, maximum, standard deviation, and the number of observations for some additional variables used in the robustness tests. Appendix B outlines the definitions for all the variables above. 
Table 4. Pearson correlation coefficients between variables

\begin{tabular}{|c|c|c|c|c|c|c|c|c|c|}
\hline & DIV_SALES & DIV_ASSETS & SIZE & $\mathrm{CASH}$ & GROWTH & DEBT & ROA & RE_TE & CSR_NET \\
\hline DIV_SALES & 1.00 & & & & & & & & \\
\hline \multirow[t]{2}{*}{ DIV_ASSETS } & 0.90 & 1.00 & & & & & & & \\
\hline & 0.00 & & & & & & & & \\
\hline \multirow[t]{2}{*}{ SIZE } & 0.29 & 0.23 & 1.00 & & & & & & \\
\hline & 0.00 & 0,00 & & & & & & & \\
\hline \multirow[t]{2}{*}{ CASH } & -0.17 & -0.17 & -0.45 & 1.00 & & & & & \\
\hline & 0.00 & 0,00 & 0.00 & & & & & & \\
\hline \multirow[t]{2}{*}{ GROWTH } & -0.13 & -0.12 & -0.08 & 0.09 & 1.00 & & & & \\
\hline & 0.00 & 0.00 & 0.00 & 0.00 & & & & & \\
\hline \multirow[t]{2}{*}{ DEBT } & 0.06 & 0.00 & 0.36 & -0.41 & -0.07 & 1.00 & & & \\
\hline & 0.00 & 0.98 & 0.00 & 0.00 & 0.00 & & & & \\
\hline \multirow[t]{2}{*}{ ROA } & 0.26 & 0.31 & 0.21 & -0.21 & 0.16 & -0.15 & 1.00 & & \\
\hline & 0.00 & 0.00 & 0.00 & 0.00 & 0.00 & 0.00 & & & \\
\hline \multirow[t]{2}{*}{ RE_TE } & 0.26 & 0.30 & 0.33 & -0.37 & -0.06 & 0.01 & 0.49 & 1.00 & \\
\hline & 0.00 & 0.00 & 0.00 & 0.00 & 0.00 & 0.32 & 0.00 & & \\
\hline \multirow[t]{2}{*}{ CSR_NET } & 0.16 & 0.18 & 0.14 & 0.02 & -0.02 & -0.05 & 0.11 & 0.11 & 1.00 \\
\hline & 0.00 & 0.00 & 0.00 & 0.01 & 0.01 & 0.00 & 0.00 & 0.00 & \\
\hline
\end{tabular}

This table provides pearson pair-wise correlation coefficients between dependent variables, overall corporate social responsibility score, and the control variables for the 22,389 firm-year observations between 1991 and 2012. Financial firms (SIC codes 6000-6999) and utility firms (sic between 4900 and 4999) are excluded. Appendix B provides definitions for regression variables as well as for corporate social responsibility data. Correlation coefficients in boldface are significant at least at the 5\% level. 
Table 5. Univariate tests for CSR versus non-CSR firms

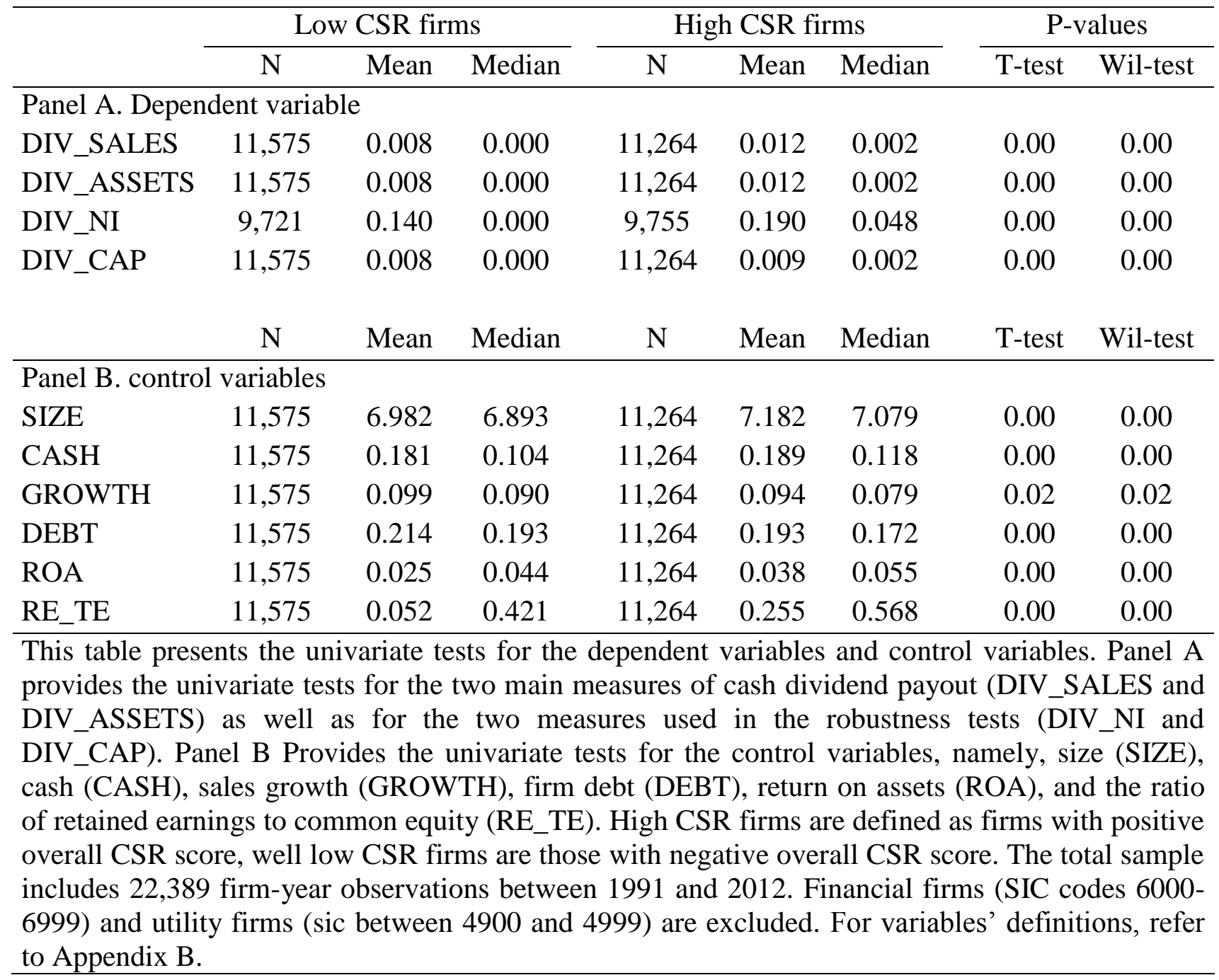


Figure1. Dividend payout for socially responsible-non responsible firms. This figure plots the evolution of the annual average of cash dividend to net sales ratio for socially responsible firms (defined as firms with positive overall CSR score) versus non socially responsible firms (defined as firms with negative overall CSR score). The sample consists of observations of Compustat and KLD between 1991 and 2012. Financial firms (SIC codes 6000-6999) and utility firms (sic between 4900 and 4999) are excluded.

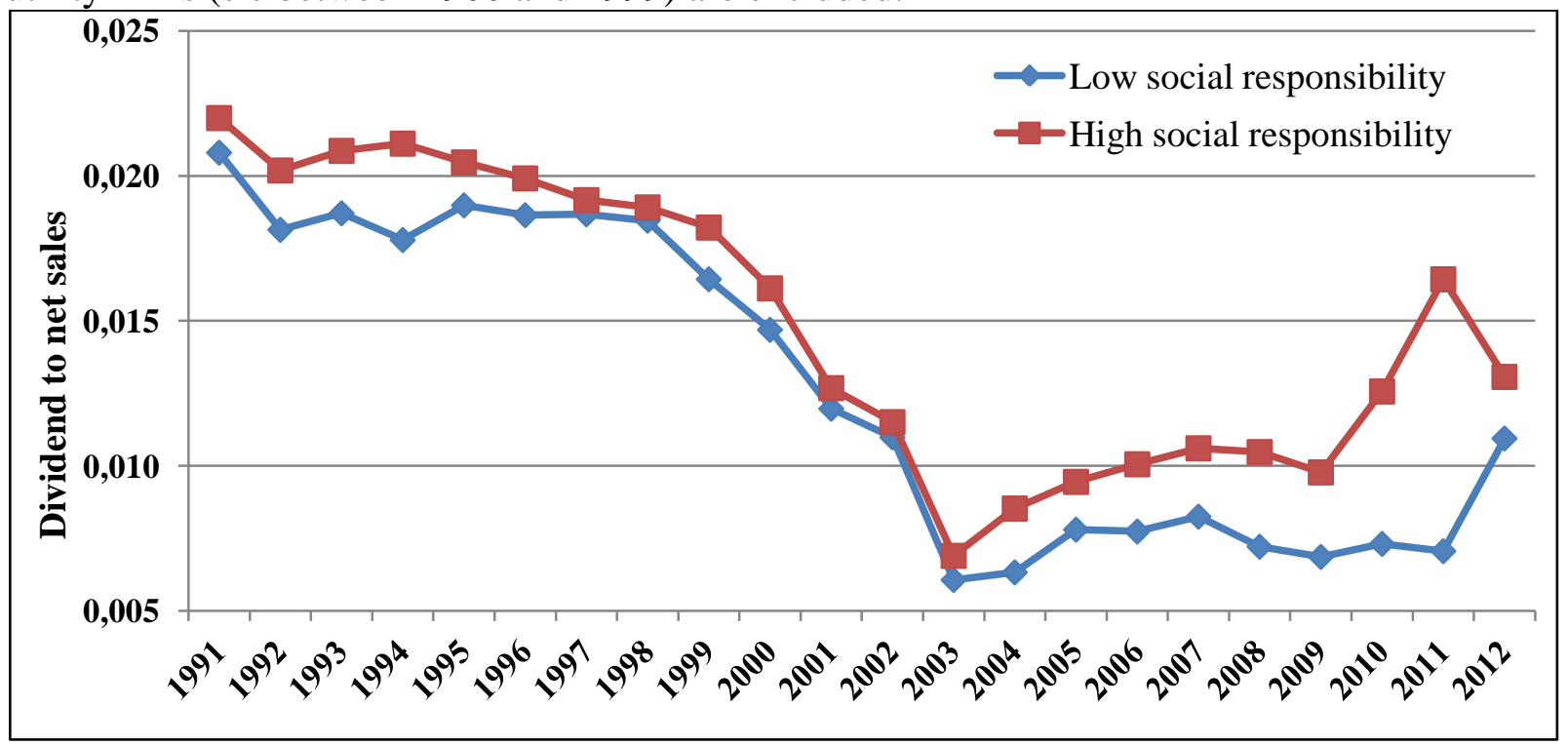

Figure2. Dividend payout for socially responsible (non responsible) firms. This figure plots the evolution of the annual average of cash dividend to total assets ratio for socially responsible firms (defined as firms with positive overall CSR score) versus non socially responsible firms (defined as firms with negative overall CSR score). The sample consists of observations of Compustat and KLD between 1991 and 2012. Financial firms (SIC codes 6000-6999) and utility firms (sic between 4900 and 4999) are excluded.

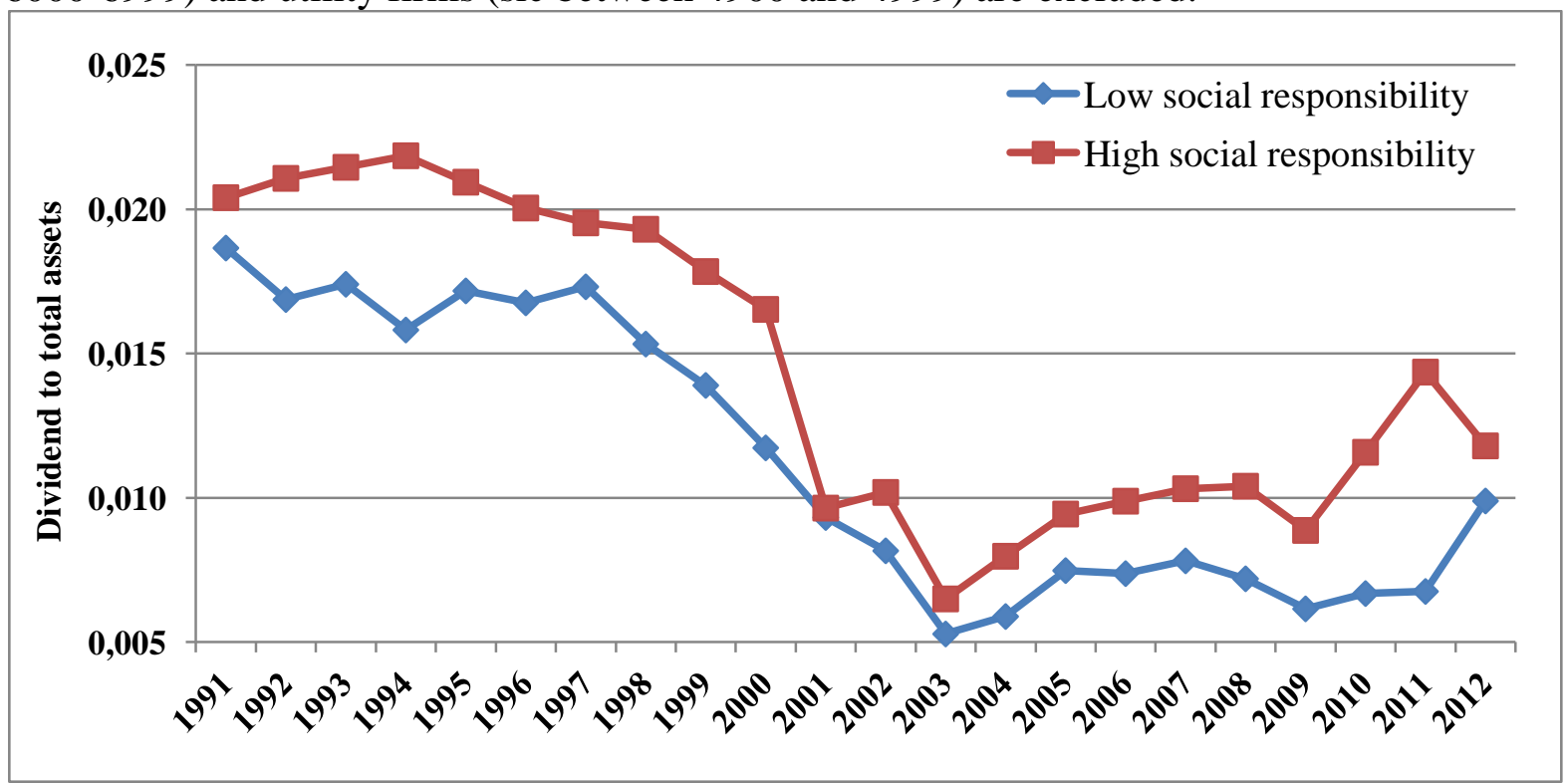


Table 6. Corporate social responsibility and dividend policy

\begin{tabular}{|c|c|c|c|c|c|c|c|c|c|c|c|c|}
\hline & \multicolumn{6}{|c|}{ DIV_SALES } & \multicolumn{6}{|c|}{ DIV_ASSETS } \\
\hline & Simple & Main & 1991-1996 & 1997-2002 & 2003-2007 & $2008-2012$ & Simple & Main & 1991-1996 & $1997-2002$ & $2003-2007$ & $2008-2012$ \\
\hline & $(1)$ & $(2)$ & (3) & (4) & $(5)$ & (6) & $(7)$ & $(8)$ & $(9)$ & $(10)$ & $(11)$ & $(12)$ \\
\hline \multirow[t]{2}{*}{ INTERCEPT } & $0.028 * * *$ & 0.011 & $0.021 * * *$ & $0.018 * * *$ & 0.005 & 0.006 & $0.011 * * *$ & 0.003 & 0.007 & 0.002 & 0.001 & 0.002 \\
\hline & $(2.71)$ & (1.08) & (3.87) & $(4.05)$ & $(0.48)$ & $(0.62)$ & (4.94) & (1.16) & $(1.35)$ & $(0.56)$ & $(0.40)$ & $(0.61)$ \\
\hline \multirow[t]{2}{*}{ CSR_NET } & $0.001 * * *$ & $0.001 * * *$ & 0.000 & $0.001 *$ & $0.001 * * *$ & $0.001 * * *$ & $0.001 * * *$ & $0.001 * * *$ & 0.000 & $0.001 * *$ & $0.001 * * *$ & $0.001 * * *$ \\
\hline & $(7.23)$ & $(5.31)$ & $(1.56)$ & $(1.83)$ & $(4.01)$ & $(7.88)$ & $(7.48)$ & $(5.94)$ & $(1.07)$ & $(2.48)$ & $(4.40)$ & (8.39) \\
\hline \multirow[t]{2}{*}{ SIZE } & & $0.002 * * *$ & $0.002 * * *$ & $0.003 * * *$ & $0.002 * * *$ & $0.001 * * *$ & & $0.001 * * *$ & $0.002 * * *$ & $0.001 * * *$ & $0.001 * * *$ & $0.001 * * *$ \\
\hline & & $(7.91)$ & (3.72) & $(6.33)$ & (6.63) & $(5.81)$ & & $(4.38)$ & $(2.63)$ & $(2.86)$ & (4.19) & $(2.76)$ \\
\hline \multirow[t]{2}{*}{ CASH } & & 0.001 & $-0.024 * * *$ & $-0.016 * * *$ & 0.002 & 0.003 & & -0.002 & $-0.034 * * *$ & $-0.019 * * *$ & -0.001 & 0.001 \\
\hline & & $(0.33)$ & $(-3.68)$ & $(-4.86)$ & (1.09) & $(1.49)$ & & $(-1.49)$ & $(-5.41)$ & $(-6.49)$ & $(-0.39)$ & $(0.77)$ \\
\hline \multirow[t]{2}{*}{ GROWTH } & & $-0.013 * * *$ & $-0.027 * * *$ & $-0.014 * * *$ & $-0.010 * * *$ & $-0.010 * * *$ & & $-0.012 * * *$ & $-0.024 * * *$ & $-0.011 * * *$ & $-0.010 * * *$ & $-0.008 * * *$ \\
\hline & & $(-16.93)$ & $(-7.28)$ & $(-7.33)$ & $(-10.39)$ & $(-11.49)$ & & $(-17.20)$ & $(-7.25)$ & $(-6.68)$ & $(-11.39)$ & $(-11.01)$ \\
\hline \multirow[t]{2}{*}{ DEBT } & & -0.002 & $-0.017 * * *$ & -0.005 & -0.001 & 0.000 & & $-0.004 * * *$ & $-0.028 * * *$ & $-0.006 *$ & $-0.003 * *$ & -0.002 \\
\hline & & $(-1.23)$ & $(-2.97)$ & $(-1.37)$ & $(-0.53)$ & $(-0.09)$ & & $(-3.05)$ & $(-5.66)$ & $(-1.93)$ & $(-1.96)$ & $(-1.07)$ \\
\hline \multirow[t]{2}{*}{ ROA } & & $0.033 * * *$ & $0.060 * * *$ & $0.037 * * *$ & $0.029 * * *$ & $0.034 * * *$ & & $0.035 * * *$ & $0.064 * * *$ & $0.043 * * *$ & $0.030 * * *$ & $0.034 * * *$ \\
\hline & & $(13.91)$ & $(6.56)$ & (6.37) & (10.07) & $(12.35)$ & & (14.74) & (7.74) & (6.74) & $(10.82)$ & (12.94) \\
\hline \multirow[t]{2}{*}{ RE_TE } & & $0.001 * * *$ & $0.004 * * *$ & $0.003 * * *$ & $0.001 * * *$ & $0.001 * * *$ & & $0.001 * * *$ & $0.004 * * *$ & $0.002 * * *$ & $0.001 * * *$ & $0.001 * * *$ \\
\hline & & $(8.26)$ & $(4.36)$ & (4.69) & (6.86) & $(5.65)$ & & (8.67) & $(4.46)$ & (3.19) & (7.37) & (6.59) \\
\hline Year effects & Yes & Yes & No & No & No & No & Yes & Yes & No & No & No & No \\
\hline Industry & Yes & Yes & Yes & Yes & Yes & Yes & Yes & Yes & Yes & Yes & Yes & Yes \\
\hline Adj. R2 \% & 16.34 & 27.41 & 51.22 & 43.07 & 24.14 & 21.62 & 16.68 & 27.65 & 50.78 & 40.24 & 23.8 & 21.58 \\
\hline $\mathrm{N}$ & 22,389 & 22,389 & 1,636 & 2,540 & 8,784 & 9,879 & 22,389 & 22,389 & 1,636 & 2,540 & 8,784 & 9,879 \\
\hline
\end{tabular}

This table reports the results from regressing dividends on overall CSR score and other control variables over the period 1991-2012 for the 22,389 firm-year observations of the sample. Models 1 and 2 regress cash dividends (measured as the ratio of dividends to net sales) on overall CSR score for the entire sample period. Models 3-6 replicate Model 2 after dividing the total sample period into four sub-periods. Models 7 and 8 regress cash dividends (measured as the ratio of dividends to total assets) on overall CSR score for the entire sample period. Models 9-12 replicate Model 8 after dividing the total sample period into four sub-periods. The control variables are size (SIZE), cash (CASH), sales growth (GROWTH), firm debt (DEBT), return on assets (ROA), and the ratio of retained earnings to common equity (RE_TE). Appendix B outlines the definitions for all the regression variables. All financial variables have been winsorized at the 5\% level. Unreported industry controls are based on the two-digit code of the Standard Industrial Classification. Financial firms (SIC codes 6000-6999) and utility firms (sic between 4900 and 4999) are excluded from the analysis. Robust t-statistics corrected for clustering at the firm level are presented in parentheses.

*statistical significance at the $10 \%$ level.

**statistical significance at the $5 \%$ level.

$* * *$ statistical significance at the $1 \%$ level. 
Table 7. Individual components of corporate social responsibility and dividend policy

\begin{tabular}{|c|c|c|c|c|c|c|c|c|c|c|c|c|}
\hline & \multicolumn{7}{|c|}{ DIV_SALES } & \multicolumn{5}{|c|}{ DIV_ASSETS } \\
\hline & CGOV_NET & EMPL_NET & DIV_NET & COM_NET & PRO_NET & ENV_NET & CGOV_NET & EMPL_NET & DIV_NET & COM_NET & PRO_NET & ENV_NET \\
\hline & $(1)$ & $(2)$ & (3) & (4) & $(5)$ & (6) & $(7)$ & $(8)$ & $(9)$ & $(10)$ & $(11)$ & $(12)$ \\
\hline \multirow[t]{2}{*}{ INTERCEPT } & 0.008 & 0.009 & 0.013 & 0.010 & 0.010 & 0.010 & 0.001 & 0.002 & $0.005^{*}$ & 0.002 & 0.002 & 0.002 \\
\hline & $(0.73)$ & $(0.93)$ & (1.34) & (1.03) & (1.01) & $(0.95)$ & $(0.18)$ & $(0.51)$ & $(1.81)$ & $(0.72)$ & $(0.54)$ & $(0.80)$ \\
\hline \multirow[t]{2}{*}{ CSR_COM } & $0.002 * * *$ & $0.001 * * *$ & $0.001 * * *$ & $0.002 * * *$ & $-0.002 * * *$ & 0.000 & $0.001 * * *$ & $0.001 * * *$ & $0.001 * * *$ & $0.002 * * *$ & $-0.001 * * *$ & $0.001 *$ \\
\hline & $(5.79)$ & (3.39) & $(5.97)$ & (3.78) & $(-3.67)$ & $(1.37)$ & (4.92) & $(3.26)$ & (6.58) & (4.32) & $(-2.59)$ & $(1.85)$ \\
\hline \multirow[t]{2}{*}{ SIZE } & $0.002 * * *$ & $0.002 * * *$ & $0.001 * * *$ & $0.002 * * *$ & $0.002 * * *$ & $0.002 * * *$ & $0.001 * * *$ & $0.001 * * *$ & $0.001 * *$ & $0.001 * * *$ & $0.001 * * *$ & $0.001 * * *$ \\
\hline & $(9.26)$ & $(8.37)$ & $(6.45)$ & (8.07) & $(7.93)$ & (8.37) & $(5.85)$ & $(5.00)$ & $(2.51)$ & $(4.42)$ & $(4.58)$ & $(5.05)$ \\
\hline \multirow[t]{2}{*}{ CASH } & 0.002 & 0.001 & 0.000 & 0.001 & 0.001 & 0.001 & -0.001 & -0.002 & $-0.002 *$ & -0.002 & -0.001 & -0.001 \\
\hline & (1.02) & $(0.61)$ & $(0.19)$ & $(0.55)$ & $(0.79)$ & $(0.68)$ & $(-0.78)$ & $(-1.14)$ & $(-1.64)$ & $(-1.23)$ & $(-0.97)$ & $(-1.10)$ \\
\hline \multirow[t]{2}{*}{ GROWTH } & $-0.013 * * *$ & $-0.013 * * *$ & $-0.012 * * *$ & $-0.013 * * *$ & $-0.013 * * *$ & $-0.013 * * *$ & $-0.012 * * *$ & $-0.012 * * *$ & $-0.011 * * *$ & $-0.012 * * *$ & $-0.011 * * *$ & $-0.012 * * *$ \\
\hline & $(-17.20)$ & $(-16.97)$ & $(-16.45)$ & $(-16.84)$ & $(-16.79)$ & $(-16.92)$ & $(-17.37)$ & $(-17.23)$ & $(-16.77)$ & $(-17.13)$ & $(-17.01)$ & $(-17.17)$ \\
\hline \multirow[t]{2}{*}{ DEBT } & -0.002 & -0.002 & -0.002 & -0.002 & -0.002 & -0.002 & $-0.004 * * *$ & $-0.004 * * *$ & $-0.004 * * *$ & $-0.004 * * *$ & $-0.004 * * *$ & $-0.004 * * *$ \\
\hline & $(-1.45)$ & $(-1.35)$ & $(-1.07)$ & $(-1.27)$ & $(-1.32)$ & $(-1.42)$ & $(-3.28)$ & $(-3.19)$ & $(-2.86)$ & $(-3.10)$ & $(-3.18)$ & $(-3.27)$ \\
\hline \multirow[t]{2}{*}{ ROA } & $0.034 * * *$ & $0.033 * * *$ & $0.034 * * *$ & $0.034 * * *$ & $0.034 * * *$ & $0.034 * * *$ & $0.035 * * *$ & $0.035 * * *$ & $0.035 * * *$ & $0.035 * * *$ & $0.036 * * *$ & $0.035 * * *$ \\
\hline & $(13.87)$ & $(13.86)$ & $(14.07)$ & (13.99) & $(13.95)$ & $(13.93)$ & $(14.58)$ & $(14.57)$ & $(14.91)$ & $(14.76)$ & $(14.63)$ & $(14.64)$ \\
\hline \multirow[t]{2}{*}{ RE_TE } & $0.001 * * *$ & $0.001 * * *$ & $0.001 * * *$ & $0.001 * * *$ & $0.001 * * *$ & $0.001 * * *$ & $0.001 * * *$ & $0.001 * * *$ & $0.001 * * *$ & $0.001 * * *$ & $0.001 * * *$ & $0.001 * * *$ \\
\hline & $(8.41)$ & (8.36) & $(8.58)$ & $(8.44)$ & $(8.65)$ & $(8.52)$ & $(8.86)$ & $(8.80)$ & $(9.03)$ & $(8.85)$ & $(9.01)$ & (8.93) \\
\hline Year effects & Yes & Yes & Yes & Yes & Yes & Yes & Yes & Yes & Yes & Yes & Yes & Yes \\
\hline Industry & Yes & Yes & Yes & Yes & Yes & Yes & Yes & Yes & Yes & Yes & Yes & Yes \\
\hline Adj. R2 \% & 27.11 & 26.95 & 27.53 & 27.22 & 27.17 & 26.8 & 27.12 & 27.03 & 27.81 & 27.42 & 27.07 & 26.93 \\
\hline $\mathrm{N}$ & 22,389 & 22,389 & 22,389 & 22,389 & 22,389 & 22,389 & 22,389 & 22,389 & 22,389 & 22,389 & 22,389 & 22,389 \\
\hline
\end{tabular}

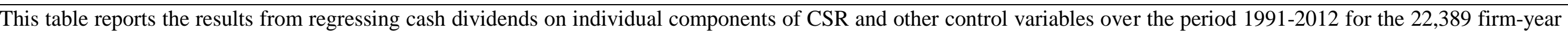

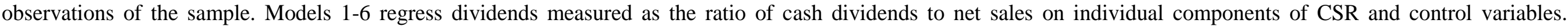

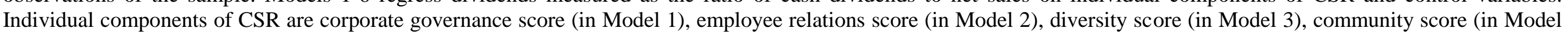

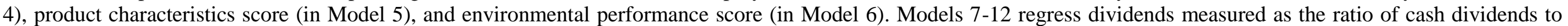

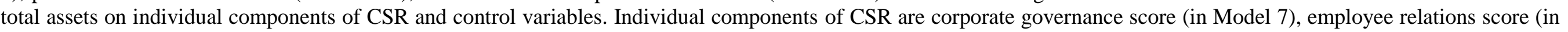

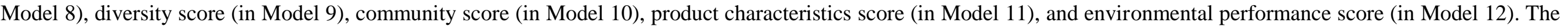

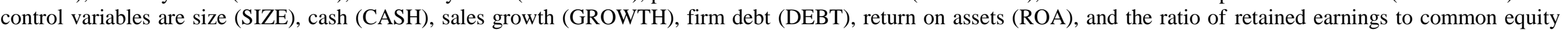

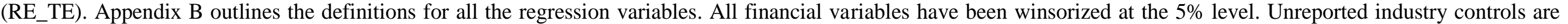

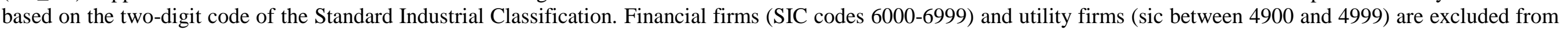
the analysis. Robust t-statistics corrected for clustering at the firm level are presented in parentheses.

*statistical significance at the $10 \%$ level.

**statistical significance at the $5 \%$ level.

****statistical significance at the $1 \%$ level. 
Table 8. Lintner (1956) model estimates for high and low CSR firms

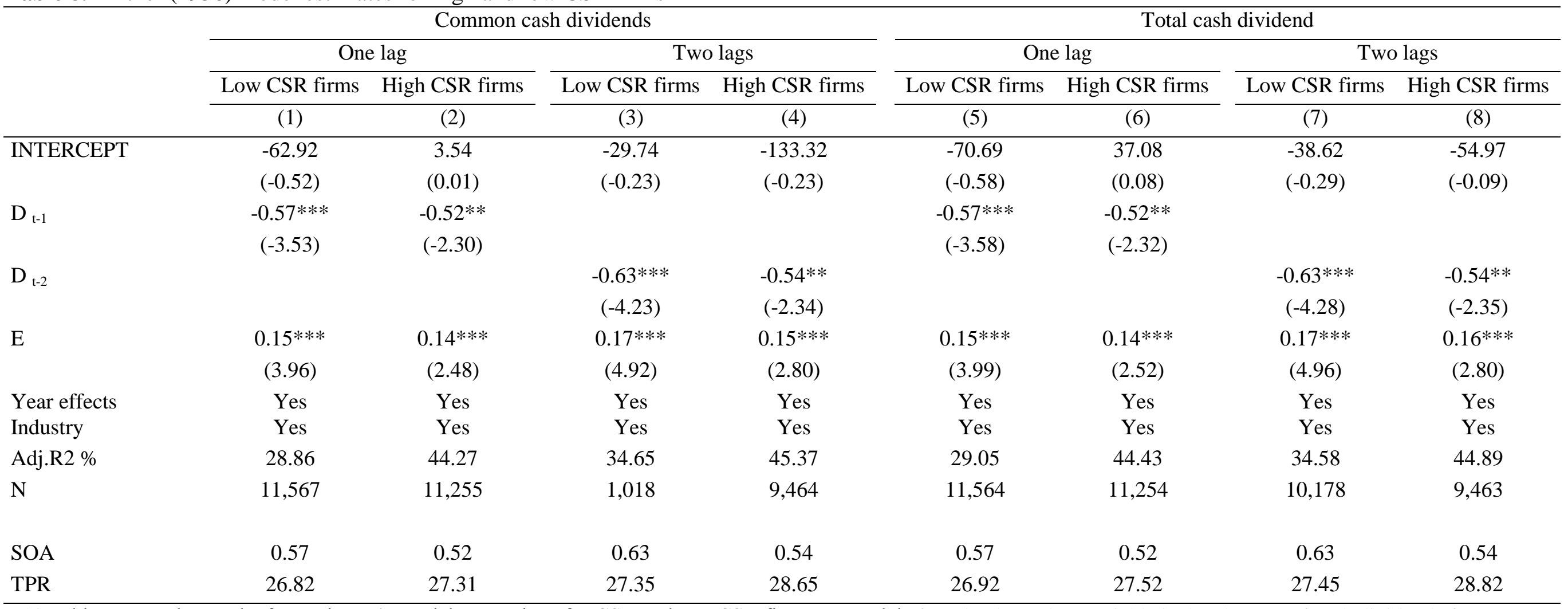

This table reports the results from Lintner's model regressions for CSR and non CSR firms. In Models 1-2, the dependent variable is the changes of cash dividends from year t-

1 to year $\mathrm{t}$ (changes of total cash dividends-the sum of common cash and preferred cash dividends- in Models 5-6). In Models 3-4 the dependent variable is the changes of cash dividends from year $\mathrm{t}-2$ to year $\mathrm{t}$ (changes of total cash dividends-the sum of common cash and preferred cash dividends- in Models 7-8). The independent variables are the earnings before interest but after taxes (E), and the lagged value of cash dividend measure $D_{t-1}$ (two lags of dividend measure - $D_{t-2}$ - for the models which use as dependent variable changes from year t-2 to year t). CSR firms are those with positive overall CSR score, while non CSR firms are those with negative overall CSR score. Unreported industry controls are based on the two-digit code of the Standard Industrial Classification. Financial firms (SIC codes 6000-6999) and utility firms (sic between 4900 and 4999) are excluded from the analysis. The speed of adjustment (SOA) is estimated as $-\beta 1$, and the target payout ratio (TPR) is estimated as $-\beta 2 / \beta 1$. Robust $t$-statistics corrected for clustering at the firm level are presented in parentheses.

*statistical significance at the $10 \%$ level.

**statistical significance at the $5 \%$ level.

***statistical significance at the $1 \%$ level. 
Table 9. Lintner (1956) model estimates for high and low CSR firms (measured by individual components of CSR)

\begin{tabular}{|c|c|c|c|c|c|c|c|c|c|c|c|c|}
\hline & \multicolumn{2}{|c|}{ Corporate Governance } & \multicolumn{2}{|c|}{ Employee relations } & \multicolumn{2}{|c|}{ Diversity } & \multicolumn{2}{|c|}{ Community } & \multicolumn{2}{|c|}{ Product characteristics } & \multicolumn{2}{|c|}{ Environment } \\
\hline & $\begin{array}{l}\text { Low CGOV } \\
\text { firms }\end{array}$ & $\begin{array}{l}\text { High CGOV } \\
\text { firms }\end{array}$ & $\begin{array}{l}\text { Low EMPL } \\
\text { firms }\end{array}$ & $\begin{array}{l}\text { High EMPL } \\
\text { firms }\end{array}$ & $\begin{array}{l}\text { Low DIV } \\
\text { firms }\end{array}$ & $\begin{array}{l}\text { High DIV } \\
\text { firms }\end{array}$ & $\begin{array}{l}\text { Low COM } \\
\text { firms }\end{array}$ & $\begin{array}{l}\text { High COM } \\
\text { firms }\end{array}$ & $\begin{array}{l}\text { Low PRO } \\
\text { firms }\end{array}$ & $\begin{array}{l}\text { High PRO } \\
\text { firms }\end{array}$ & $\begin{array}{l}\text { Low ENV } \\
\text { firms }\end{array}$ & $\begin{array}{l}\text { High ENV } \\
\text { firms }\end{array}$ \\
\hline & $(1)$ & $(2)$ & (3) & (4) & $(5)$ & (6) & $(7)$ & $(8)$ & $(9)$ & $(10)$ & $(11)$ & $(12)$ \\
\hline \multirow[t]{2}{*}{ INTERCEPT } & -301.907 & 93.322 & 102.676 & 68.800 & -11.813 & -34.261 & -111.768 & -39.010 & 19.920 & 3.943 & 96.359 & -382.520 \\
\hline & $(-1.10)$ & $(0.68)$ & $(0.89)$ & $(0.22)$ & $(-1.05)$ & $(-0.13)$ & $(-1.31)$ & $(-0.18)$ & $(0.03)$ & $(1.06)$ & $(0.70)$ & $(-1.27)$ \\
\hline \multirow[t]{2}{*}{ Dt-1 } & $-0.420 * *$ & $-0.603 * * *$ & -0.297 & $-0.578 * * *$ & $-0.596 * * *$ & $-0.533 * * *$ & $-0.772 * * *$ & $-0.495 * *$ & $-0.634 * * *$ & $-0.173 * * *$ & $-0.562 * * *$ & $-0.509 * *$ \\
\hline & $(-2.50)$ & $(-2.82)$ & $(-1.58)$ & $(-3.36)$ & $(-4.42)$ & $(-3.08)$ & $(-4.27)$ & $(-2.50)$ & $(-3.82)$ & $(-2.81)$ & $(-2.90)$ & $(-2.32)$ \\
\hline \multirow[t]{2}{*}{$\mathrm{E}$} & $0.125 * * *$ & $0.155 * * *$ & $0.115^{* *}$ & $0.146 * * *$ & $0.168 * * *$ & $0.145^{* * *}$ & $0.209 * * *$ & $0.136 * * *$ & $0.167 * * *$ & $0.058 * * *$ & $0.139 * * *$ & $0.161 * * *$ \\
\hline & $(3.00)$ & (2.69) & $(2.38)$ & $(3.32)$ & (3.74) & $(3.29)$ & $(4.71)$ & $(2.79)$ & $(3.43)$ & $(3.78)$ & (2.94) & $(2.66)$ \\
\hline Year effects & Yes & Yes & Yes & Yes & Yes & Yes & Yes & Yes & Yes & Yes & Yes & Yes \\
\hline Industry & Yes & Yes & Yes & Yes & Yes & Yes & Yes & Yes & Yes & Yes & Yes & Yes \\
\hline Adj.R2 \% & 22.62 & 49.22 & 9.08 & 49.28 & 20.73 & 39.05 & 36.09 & 39.92 & 47.41 & 8.87 & 25.62 & 44.71 \\
\hline $\mathrm{N}$ & 7,791 & 15,301 & 5,939 & 16,883 & 8,323 & 14,499 & 910 & 21,912 & 3,147 & 19,675 & 2,470 & 20,352 \\
\hline SOA & 0.42 & 0.60 & NS & 0.58 & 0.60 & 0.53 & 0.77 & 0.50 & 0.63 & 0.17 & 0.56 & 0.51 \\
\hline TPR & 29.88 & 25.75 & 38.84 & 25.17 & 28.28 & 27.15 & 27.01 & 27.50 & 26.38 & 33.76 & 24.73 & 31.71 \\
\hline
\end{tabular}

This table reports the results from Lintner's model regressions for CSR and non CSR firms measured by individual components of CSR. The dependent variable is the changes of cash dividends from year $\mathrm{t}-1$ to year $\mathrm{t}$. The independent variables are the lagged value of dividends measure $\left(\mathrm{D}_{\mathrm{t}-1}\right)$, and earnings before interest but after taxes (E). The sample is split according to the level of CSR score measured by individual components with low CSR firms are those with negative individual score, and firms with CSR firms are those with positive score for the same dimension. Individual components of CSR are corporate governance (CGOV in Models 1 and 2), employee relations (EMPL in Models 3 and 4), diversity (DIV in Models 5 and 6), community (COM in Models 7 and 8), product characteristics (PRO in Models 9 and 10), and environment (ENV in Models 11 and 12). Unreported industry controls are based on the two-digit code of the Standard Industrial Classification. Financial firms (SIC codes 6000-6999) and utility firms (sic between 4900 and 4999) are excluded from the analysis. The speed of adjustment (SOA) is estimated as $-\beta 1$, and the target payout ratio (TPR) is estimated as - $\beta 2 / \beta 1$. Robust $t$-statistics corrected for clustering at the firm level are presented in parentheses.

*statistical significance at the $10 \%$ level.

**statistical significance at the $5 \%$ level.

$* * *$ statistical significance at the $1 \%$ level. 
Table 10. Robustness tests: alternative estimations and standard errors

\begin{tabular}{|c|c|c|c|c|c|c|c|c|c|c|}
\hline & \multicolumn{5}{|c|}{ DIV_SALES } & \multicolumn{5}{|c|}{ DIV_ASSETS } \\
\hline & $\begin{array}{l}\text { Firm Fixed } \\
\text { Effects }\end{array}$ & $\begin{array}{l}\text { Firm Random } \\
\text { Effects }\end{array}$ & Bootsrapping & $\begin{array}{l}\text { Fama- } \\
\text { McBeth }\end{array}$ & White & $\begin{array}{l}\text { Firm Fixed } \\
\text { Effects }\end{array}$ & $\begin{array}{l}\text { Firm Random } \\
\text { Effects }\end{array}$ & Bootsrapping & $\begin{array}{l}\text { Fama- } \\
\text { McBeth }\end{array}$ & White \\
\hline & (1) & (2) & (3) & (4) & (5) & (6) & (7) & (8) & (9) & (10) \\
\hline INTERCEPT & $\begin{array}{c}0.002 * * * \\
(4.73)\end{array}$ & $\begin{array}{l}0.003 * * * \\
(2.83)\end{array}$ & $\begin{array}{c}0.011 * * * \\
(47.73)\end{array}$ & $\begin{array}{c}0.014 * * * \\
(7.38)\end{array}$ & $\begin{array}{c}0.011 * * * \\
(3.82)\end{array}$ & $\begin{array}{c}0.027 * * * \\
(7.82)\end{array}$ & $\begin{array}{l}0.008^{* * * *} \\
(9.91)\end{array}$ & $\begin{array}{c}0.003 * * * \\
(31.19)\end{array}$ & $\begin{array}{c}0.004 * * * \\
(4.06)\end{array}$ & $\begin{array}{c}0.003^{* * * *} \\
(2.94)\end{array}$ \\
\hline CSR_NET & $\begin{array}{c}0.000 * * * \\
(7.23)\end{array}$ & $\begin{array}{c}0.000 * * * \\
(9.26)\end{array}$ & $\begin{array}{c}0.001 * * * \\
(128.73)\end{array}$ & $\begin{array}{c}0.001 * * * \\
(9.47)\end{array}$ & $\begin{array}{c}0.001 * * * \\
(12.44)\end{array}$ & $\begin{array}{l}0.000 * * * \\
(5.46)\end{array}$ & $\begin{array}{c}0.000 * * * \\
(8.15)\end{array}$ & $\begin{array}{l}0.001 * * * \\
(157.97)\end{array}$ & $\begin{array}{c}0.001 * * * \\
(8.07)\end{array}$ & $\begin{array}{c}0.001 * * * \\
(13.99)\end{array}$ \\
\hline SIZE & $\begin{array}{c}0.000 \\
(-1.00)\end{array}$ & $\begin{array}{c}0.001 * * * \\
(10.26)\end{array}$ & $\begin{array}{c}0.002 * * * \\
(222.43)\end{array}$ & $\begin{array}{c}0.002 * * * \\
(12.45)\end{array}$ & $\begin{array}{c}0.002 * * * \\
(21.22)\end{array}$ & $\begin{array}{c}-0.001 * * * \\
(-7.61)\end{array}$ & $\begin{array}{c}0.000^{* *} \\
(3.34)\end{array}$ & $\begin{array}{c}0.001 * * * \\
(117.01)\end{array}$ & $\begin{array}{c}0.001 * * * \\
(6.70)\end{array}$ & $\begin{array}{c}0.001 * * * \\
(11.66)\end{array}$ \\
\hline $\mathrm{CASH}$ & $\begin{array}{c}0.002 * * * \\
(3.07)\end{array}$ & $\begin{array}{l}0.001 \\
(1.21)\end{array}$ & $\begin{array}{c}0.000 * * * \\
(6.29)\end{array}$ & $\begin{array}{c}-0.012 * * * \\
(-3.46)\end{array}$ & $\begin{array}{l}0.001 \\
(0.73)\end{array}$ & $\begin{array}{l}0.000 \\
(0.31)\end{array}$ & $\begin{array}{l}-0.001 \\
(-2.16)\end{array}$ & $\begin{array}{c}-0.002 * * * \\
(-29.00)\end{array}$ & $\begin{array}{c}-0.017 * * * \\
(-4.35)\end{array}$ & $\begin{array}{c}-0.002 * * * \\
(-3.26)\end{array}$ \\
\hline GROWTH & $\begin{array}{c}-0.004 * * * \\
(-9.71)\end{array}$ & $\begin{array}{c}-0.005 * * * \\
(-11.55)\end{array}$ & $\begin{array}{c}-0.013 * * * \\
(-238.02)\end{array}$ & $\begin{array}{c}-0.018 * * * \\
(-8.46)\end{array}$ & $\begin{array}{c}-0.013 * * * \\
(-23.08)\end{array}$ & $\begin{array}{c}-0.003 * * * \\
(-7.42)\end{array}$ & $\begin{array}{c}-0.004 * * * \\
(-11.90)\end{array}$ & $\begin{array}{l}-0.012 * * * \\
-(229.41)\end{array}$ & $\begin{array}{c}-0.016 * * * \\
(-8.99)\end{array}$ & $\begin{array}{c}-0.012 * * * \\
(-24.26)\end{array}$ \\
\hline DEBT & $\begin{array}{l}-0.001 \\
(-1.20)\end{array}$ & $\begin{array}{l}-0.000 \\
(-0.08)\end{array}$ & $\begin{array}{c}-0.002 * * * \\
(-31.93)\end{array}$ & $\begin{array}{c}-0.005^{* * * *} \\
(-2.65)\end{array}$ & $\begin{array}{c}-0.002 * * * \\
(-2.70)\end{array}$ & $\begin{array}{c}-0.002 * * * \\
(-3.53)\end{array}$ & $\begin{array}{c}-0.002 * * * \\
(-3.12)\end{array}$ & $\begin{array}{c}-0.004 * * * \\
(-62.59)\end{array}$ & $\begin{array}{c}-0.010^{* * * *} \\
(-3.41)\end{array}$ & $\begin{array}{c}-0.004 * * * \\
(-6.60)\end{array}$ \\
\hline ROA & $\begin{array}{c}0.009 * * * * \\
(8.99)\end{array}$ & $\begin{array}{c}0.012 * * * \\
(13.72)\end{array}$ & $\begin{array}{l}0.033 * * * \\
(274.23)\end{array}$ & $\begin{array}{c}0.048 * * * \\
(9.04)\end{array}$ & $\begin{array}{c}0.033 * * * \\
(27.82)\end{array}$ & $\begin{array}{c}0.011 * * * \\
(12.86)\end{array}$ & $\begin{array}{c}0.015^{* * * *} \\
(18.22)\end{array}$ & $\begin{array}{l}0.035 * * * \\
(264.98)\end{array}$ & $\begin{array}{c}0.053^{* * * *} \\
(8.75)\end{array}$ & $\begin{array}{c}0.035^{* * * *} \\
(30.70)\end{array}$ \\
\hline RE_TE & $\begin{array}{c}0.000 * * * \\
(3.53)\end{array}$ & $\begin{array}{c}0.001 * * * \\
(6.46)\end{array}$ & $\begin{array}{c}0.001 * * * \\
(140.24)\end{array}$ & $\begin{array}{c}0.003 * * * \\
(6.37)\end{array}$ & $\begin{array}{c}0.001 * * * \\
(14.09)\end{array}$ & $\begin{array}{c}0.000 * * * \\
(4.17)\end{array}$ & $\begin{array}{c}0.001 * * * \\
(7.67)\end{array}$ & $\begin{array}{c}0.001 * * * \\
(146.27)\end{array}$ & $\begin{array}{c}0.003 * * * \\
(6.22)\end{array}$ & $\begin{array}{c}0.001 * * * \\
(15.03)\end{array}$ \\
\hline Year effects & Yes & Yes & Yes & Yes & Yes & Yes & Yes & Yes & Yes & Yes \\
\hline Industry & No & No & Yes & Yes & Yes & No & No & Yes & Yes & Yes \\
\hline Adj. R2 \% & 76.85 & 27.53 & - & - & 27.41 & 76.9 & 27.49 & - & - & 27.65 \\
\hline $\mathrm{N}$ & 22,389 & 22,389 & 22,389 & 22,389 & 22,389 & 22,389 & 22,389 & 22,389 & 22,389 & 22,389 \\
\hline
\end{tabular}

This table reports results from regressing dividend payout on overall CSR score and other control variables over the period 1991-2012 for the 22,389 firm-year observations of the sample. Dividends are measured as the ratio of cash dividends to net sales (Models 1-5) and as the ratio of cash dividends to total assets (Models 6-10). We report results from fixed effects models with both time and firm fixed effects (Model 1 and 6), random effects models with firm random effects and time fixed effects (Model 2 and 4), we also report models with bootstrapping techniques using 100 random resamples of the 22,389 firm-year observations observed in our principal sample (Model 3 and 8), models with Fama-MacBeth standard errors (Model 4 and 9), and finally models with white standard errors (Model 5 and 10). The control variables are size (SIZE), cash (CASH), sales growth (GROWTH), firm debt (DEBT), return on assets (ROA), and the ratio of retained earnings to common equity (RE TE). Appendix B outlines the definitions for all the regression variables. All financial variables have been winsorized at the 5\% level. Unreported industry controls are based on the two-digit code of the Standard Industrial Classification. Financial firms (SIC codes 6000-6999) and utility firms (sic between 4900 and 4999) are excluded from the analysis.

*statistical significance at the $10 \%$ level.

**statistical significance at the $5 \%$ level.

****statistical significance at the $1 \%$ level. 
Table 11. Robustness tests: alternative measures of dividend

\begin{tabular}{|c|c|c|c|c|c|c|c|}
\hline & & \multicolumn{6}{|c|}{ Dividend payments } \\
\hline & DIV_NI & DIV_CAP & LOG_DIV & TDIV_ASSETS & TDIV_SALES & LOG_TDIV & DUMMY \\
\hline & $(1)$ & $(2)$ & $(3)$ & (4) & (5) & (6) & $(7)$ \\
\hline \multirow[t]{2}{*}{ INTERCEPT } & $0.193 * *$ & $0.007 *$ & $-3.39 * * *$ & 0.004 & 0.015 & -1.141 & -0.113 \\
\hline & $(2.04)$ & $(1.92)$ & $(-2.87)$ & $(1.25)$ & $(1.30)$ & $(-1.30)$ & $(0.04)$ \\
\hline \multirow[t]{2}{*}{ CSR_NET } & $0.003 * * *$ & $0.000 * * *$ & $0.033 * * *$ & $0.001 * * *$ & $0.001 * * *$ & $0.058^{* * *}$ & $0.024 *$ \\
\hline & $(2.85)$ & $(2.67)$ & $(4.44)$ & $(5.80)$ & $(3.52)$ & $(5.03)$ & $(2.58)$ \\
\hline \multirow[t]{2}{*}{ SIZE } & $0.016 * * *$ & $0.001 * * *$ & $1.021 * * *$ & $0.001 * * *$ & $0.001 * * *$ & $0.683 * * *$ & $0.376^{* * *}$ \\
\hline & $(5.77)$ & $(8.24)$ & $(51.62)$ & $(4.04)$ & $(3.17)$ & (26.92) & $(141.81)$ \\
\hline \multirow{2}{*}{ CASH } & $-0.106 * * *$ & $-0.005 * * *$ & $1.404 * * *$ & -0.002 & $0.010 * * *$ & $-0.201 * * *$ & $-2.711 * * *$ \\
\hline & $(-5.02)$ & $(-5.48)$ & $(7.22)$ & $(-1.49)$ & $(3.24)$ & $(-1.49)$ & (94.17) \\
\hline \multirow[t]{2}{*}{ GROWTH } & $-0.229 * * *$ & $-0.010^{* * *}$ & $-1.137 * * *$ & $-0.011 * * *$ & $-0.016 * * *$ & $-0.949 * * *$ & $-2.040 * * *$ \\
\hline & $(-17.09)$ & $(-19.16)$ & $(-10.53)$ & $(-15.82)$ & $(-8.56)$ & $(-13.53)$ & (183.39) \\
\hline \multirow[t]{2}{*}{ DEBT } & -0.007 & 0.000 & -0.043 & $-0.003 * *$ & $-0.009 * * *$ & $-0.780 * * *$ & $-0.723 * * *$ \\
\hline & $(-0.30)$ & $(-0.16)$ & $(-0.25)$ & $(-2.37)$ & $(-2.85)$ & $(-5.37)$ & (8.02) \\
\hline \multirow[t]{2}{*}{ ROA } & $0.363 * * *$ & $0.009 * * *$ & $4.897 * * *$ & $0.033 * * *$ & $0.051 * * *$ & $1.589 * * *$ & $4.372 * * *$ \\
\hline & (9.11) & $(6.40)$ & $(15.02)$ & $(13.62)$ & $(8.70)$ & $(8.24)$ & $(87.60)$ \\
\hline \multirow[t]{2}{*}{ RE_TE } & $0.031 * * *$ & $0.001 * * *$ & 0.017 & $0.001 * * *$ & $0.001 * * *$ & $0.078 * * *$ & $0.409 * * *$ \\
\hline & $(12.14)$ & $(10.23)$ & $(0.61)$ & (7.14) & $(4.00)$ & $(5.30)$ & $(101.72)$ \\
\hline Year effects & Yes & Yes & Yes & Yes & Yes & Yes & Yes \\
\hline Industry & Yes & Yes & Yes & Yes & Yes & Yes & Yes \\
\hline Adj. R2 \% & 21.45 & 27.63 & 73.10 & 25.44 & 11.75 & 68.11 & \\
\hline $\mathrm{N}$ & 19,476 & 22,389 & 10079 & 22,389 & 22,389 & 10,947 & 22,389 \\
\hline
\end{tabular}

This table reports results from regressing different alternative measures of dividend payout on overall CSR score and other control variables over the period 1991-2012 for the 22,389 firm-year observations of the sample. The alternative measures of dividend payout are the ratio of common cash dividends to net income (DIV_NI) in Model 1, the ratio of common cash dividends to market capitalization (DIV CAP) in Model 2, the logarithm of common cash dividends in Model 3, the ratio of total cash dividends (common plus preferred dividends) to total assets (TDIV_ASSETS) in Model 4, the ratio of total cash dividends (common plus preferred dividends) to net sales (TDIV_SALES) in Model 5, the logarithm of total cash dividend (common plus preferred dividends) (LOG_CDIV) in Model 6, a dummy variable that takes 1 if the firm pays dividends and 0 otherwise ( DUMMY) in Model 7. The control variables are size (SIZE), cash (CASH), sales growth (GROWTH), firm debt (DEBT), return on assets (ROA), and the ratio of retained earnings to common equity (RE_TE). Appendix B outlines the definitions for all the regression variables. All financial variables have been winsorized at the 5\% level. Unreported industry controls are based on the two-digit code of the Standard Industrial Classification. Financial firms (SIC codes 6000-6999) and utility firms (sic between 4900 and 4999) are excluded from the analysis. Robust t-statistics (z-statistics for Model 6) corrected for clustering at the firm level are presented in parentheses.

*statistical significance at the $10 \%$ level.

**statistical significance at the $5 \%$ level.

***statistical significance at the $1 \%$ level. 
Table 12. Robustness tests: alternative measures of corporate social responsibility: controversial business issues

DIV_SALES

DIV_ASSETS

\begin{tabular}{|c|c|c|c|c|c|c|c|c|c|c|c|c|}
\hline & & \\
\hline & NUC_CON & MIL_CON & ALC_CON & TOB_CON & FIR_CON & GAM_CON & NUC_CON & MIL_CON & ALC_CON & TOB_CON & FIR_CON & GAM_CON \\
\hline & (1) & (2) & (3) & (4) & (5) & (6) & (7) & (8) & (9) & (10) & (11) & (12) \\
\hline INTERCEPT & 0.008 & 0.008 & 0.008 & 0.007 & 0.007 & 0.007 & -0.001 & 0.000 & 0.000 & -0.001 & 0.000 & -0.001 \\
\hline & $(0.73)$ & $(0.75)$ & $(0.84)$ & $(0.72)$ & $(0.58)$ & $(0.73)$ & $(-0.20)$ & $(-0.15)$ & $(-0.16)$ & $(-0.43)$ & $(-0.03)$ & $(-0.43)$ \\
\hline CSR_CONT & 0.000 & $-0.003^{* *}$ & $-0.006 * *$ & 0.005 & 0.002 & 0.002 & -0.002 & $-0.003 * * *$ & $-0.006^{* *}$ & 0.001 & 0.003 & 0.000 \\
\hline & $(-0.12)$ & $(-2.25)$ & $(-1.96)$ & $(0.93)$ & $(0.31)$ & (1.11) & $(-0.87)$ & $(-2.72)$ & $(-2.00)$ & $(0.36)$ & $(0.40)$ & $(-0.04)$ \\
\hline SIZE & $0.002 * * *$ & $0.002 * * *$ & $0.002 * * *$ & $0.002 * * *$ & $0.002 * * *$ & $0.002 * * *$ & $0.001 * * *$ & $0.001 * * *$ & $0.001 * * *$ & $0.001 * * *$ & $0.001 * * *$ & $0.001 * * *$ \\
\hline & $(7.93)$ & $(8.05)$ & $(8.02)$ & $(7.95)$ & $(7.63)$ & (7.93) & $(4.73)$ & (4.95) & $(4.79)$ & $(4.71)$ & $(4.57)$ & $(4.71)$ \\
\hline CASH & $\begin{array}{c}0.000 \\
(-0.12)\end{array}$ & $\begin{array}{c}0.000 \\
(-0.24)\end{array}$ & $\begin{array}{c}0.000 \\
(-0.13)\end{array}$ & $\begin{array}{c}0.000 \\
(-0.11)\end{array}$ & $\begin{array}{l}0.001 \\
(0.43)\end{array}$ & $\begin{array}{c}0.000 \\
(-0.13)\end{array}$ & $\begin{array}{c}-0.003 * * \\
(-2.17)\end{array}$ & $\begin{array}{c}-0.003 * * * \\
(-2.31)\end{array}$ & $\begin{array}{c}-0.003 * * \\
(-2.19)\end{array}$ & $\begin{array}{c}-0.003 * * \\
(-2.18)\end{array}$ & $\begin{array}{l}-0.002 \\
(-1.31)\end{array}$ & $\begin{array}{c}-0.003 * * \\
(-2.18)\end{array}$ \\
\hline GROWTH & $\begin{array}{c}-0.013 * * * \\
(-15.27)\end{array}$ & $\begin{array}{c}-0.013 * * * \\
(-15.27)\end{array}$ & $\begin{array}{c}-0.013 * * * \\
(-15.26)\end{array}$ & $\begin{array}{c}-0.013 * * * \\
(-15.22)\end{array}$ & $\begin{array}{c}-0.012 * * * \\
(-14.19)\end{array}$ & $\begin{array}{c}-0.013 * * * \\
(-15.26)\end{array}$ & $\begin{array}{c}-0.012 * * * \\
(-15.59)\end{array}$ & $\begin{array}{c}-0.012 * * * \\
(-15.57)\end{array}$ & $\begin{array}{c}-0.012 * * * \\
(-15.57)\end{array}$ & $\begin{array}{c}-0.012 * * * \\
(-15.56)\end{array}$ & $\begin{array}{c}-0.011 * * * \\
(-14.76)\end{array}$ & $\begin{array}{c}-0.012 * * * \\
(-15.59)\end{array}$ \\
\hline DEBT & $\begin{array}{c}-0.003 * * \\
(-1.96)\end{array}$ & $\begin{array}{c}-0.003 * * \\
(-2.01)\end{array}$ & $\begin{array}{c}-0.003 * * \\
(-2.04)\end{array}$ & $\begin{array}{c}-0.003 * * \\
(-1.99)\end{array}$ & $\begin{array}{l}-0.002 \\
(-1.08)\end{array}$ & $\begin{array}{c}-0.003 * * \\
(-2.01)\end{array}$ & $\begin{array}{c}-0.005^{* * *} \\
(-3.77)\end{array}$ & $\begin{array}{c}-0.005^{* * *} \\
(-3.81)\end{array}$ & $\begin{array}{c}-0.005 * * * \\
(-3.86)\end{array}$ & $\begin{array}{c}-0.005^{* * *} \\
(-3.77)\end{array}$ & $\begin{array}{c}-0.003 * * \\
(-2.30)\end{array}$ & $\begin{array}{c}-0.005^{* * *} \\
(-3.76)\end{array}$ \\
\hline ROA & $\begin{array}{c}0.031 \text { **** } \\
(12.38)\end{array}$ & $\begin{array}{c}0.031 * * * \\
(12.35)\end{array}$ & $\begin{array}{c}0.031 * * * \\
(12.34)\end{array}$ & $\begin{array}{c}0.031 * * * \\
(12.39)\end{array}$ & $\begin{array}{c}0.030^{* * * *} \\
(12.06)\end{array}$ & $\begin{array}{c}0.031^{* * * *} \\
(12.34)\end{array}$ & $\begin{array}{c}0.033^{* * * *} \\
(13.04)\end{array}$ & $\begin{array}{c}0.033 * * * \\
(13.03)\end{array}$ & $\begin{array}{c}0.033 * * * \\
(12.99)\end{array}$ & $\begin{array}{c}0.033 * * * \\
(13.04)\end{array}$ & $\begin{array}{c}0.032 * * * \\
(12.62)\end{array}$ & $\begin{array}{c}0.033 * * * \\
(13.03)\end{array}$ \\
\hline RE_TE & $\begin{array}{c}0.001 * * * \\
(8.20)\end{array}$ & $\begin{array}{c}0.001 * * * \\
(8.20)\end{array}$ & $\begin{array}{c}0.001 * * * \\
(8.23)\end{array}$ & $\begin{array}{c}0.001 * * * \\
(8.17)\end{array}$ & $\begin{array}{c}0.001 * * * \\
(7.81)\end{array}$ & $\begin{array}{c}0.001 * * * \\
(8.20)\end{array}$ & $\begin{array}{c}0.001 * * * \\
(8.43)\end{array}$ & $\begin{array}{c}0.001 * * * \\
(8.43)\end{array}$ & $\begin{array}{c}0.001 * * * \\
(8.46)\end{array}$ & $\begin{array}{c}0.001 * * * \\
(8.42)\end{array}$ & $\begin{array}{c}0.001 * * * \\
(8.10)\end{array}$ & $\begin{array}{c}0.001 * * * * \\
(8.43)\end{array}$ \\
\hline Year effects & Yes & Yes & Yes & Yes & Yes & Yes & Yes & Yes & Yes & Yes & Yes & Yes \\
\hline Industry & Yes & Yes & Yes & Yes & Yes & Yes & Yes & Yes & Yes & Yes & Yes & Yes \\
\hline Adj. R2 \% & 30.45 & 30.57 & 30.52 & 30.48 & 26.19 & 30.47 & 30.59 & 30.75 & 30.7 & 30.58 & 25.78 & 30.58 \\
\hline $\mathrm{N}$ & 16,875 & 16,875 & 16,875 & 16,875 & 14,934 & 16,875 & 16,875 & 16,875 & 16,875 & 16,875 & 14,934 & 16,875 \\
\hline
\end{tabular}

This table reports results from regressing dividend payout on alternative measures of CSR score (controversial business areas) and other control variables over the period 1991-2012 for the 22,389 firm-year observations of the sample. The alternative measures of CSR are nuclear power (NUC_CON in Models 1 and 7), military (MIL_CON in Models 2 and 8), alcohol (ALC_CON in Models 3 and 9), tobacco (TOB_CON in Models 4 and 10), firearms (FIR_CON in Models 5 and 11), gambling (GAM_CON in Models 6 and 12). Dividends are measured as the ratio of dividends to net sales (Models 1-6) and as the ratio of dividends to total assets (Models 7-12). The control variables are size (SIZE), cash (CASH), sales growth (GROWTH), firm debt (DEBT), return on assets (ROA), and the ratio of retained earnings to common equity (RE_TE). Appendix B outlines the definitions for all the regression variables. All financial variables have been winsorized at the 5\% level. Unreported industry controls are based on the two-digit code of the Standard Industrial Classification. Financial firms (SIC codes 6000-6999) and utility firms (sic between 4900 and 4999 ) are excluded from the analysis. Robust tstatistics corrected for clustering at the firm level are presented in parentheses.

*statistical significance at the $10 \%$ level.

**statistical significance at the 5\% level.

***statistical significance at the $1 \%$ level. 
Table 13. Robustness tests: additional control variables to address the endogeneity

\begin{tabular}{|c|c|c|c|c|c|c|c|c|c|c|c|c|}
\hline & \multicolumn{6}{|c|}{ DIV_SALES } & \multicolumn{6}{|c|}{ DIV_ASSETS } \\
\hline & (1) & (2) & (3) & (4) & (5) & (6) & (7) & (8) & (9) & (10) & (11) & (12) \\
\hline \multirow[t]{2}{*}{ INTERCEPT } & 0.012 & 0.011 & 0.012 & 0.007 & 0.010 & 0.006 & 0.004 & 0.003 & 0.004 & -0.001 & 0.001 & -0.002 \\
\hline & (1.13) & (1.08) & $(1.17)$ & $(0.62)$ & $(0.93)$ & $(0.58)$ & $(1.35)$ & (1.16) & $(1.32)$ & $(-0.45)$ & $(0.52)$ & $(-0.83)$ \\
\hline \multirow[t]{2}{*}{ CSR_NET } & $0.001 * * *$ & $0.001 * * *$ & $0.001 * * *$ & $0.001 * * *$ & $0.001 * * *$ & $0.001 * * *$ & $0.001 * * *$ & $0.001 * * *$ & $0.001 * * *$ & $0.001 * * *$ & $0.001 * * *$ & $0.001 * * *$ \\
\hline & $(5.26)$ & $(5.36)$ & (5.30) & (5.03) & $(5.02)$ & (4.73) & (5.89) & $(5.95)$ & (5.94) & (5.64) & (5.62) & $(5.27)$ \\
\hline \multirow[t]{2}{*}{ SIZE } & $0.002 * * *$ & $0.002 * * *$ & $0.002 * * *$ & $0.001 * * *$ & $0.002 * * *$ & $0.001 * * *$ & $0.001 * * *$ & $0.001 * * *$ & $0.001 * * *$ & 0.000 & $0.001 * * *$ & 0.000 \\
\hline & $(7.83)$ & $(7.88)$ & $(7.51)$ & (4.83) & (8.33) & $(4.85)$ & (4.29) & (4.37) & (4.12) & $(0.61)$ & (4.92) & $(0.79)$ \\
\hline \multirow[t]{2}{*}{$\mathrm{CASH}$} & 0.000 & 0.001 & 0.001 & $0.002 *$ & -0.002 & 0.001 & -0.002 & -0.002 & -0.002 & 0.000 & $-0.005 * * *$ & -0.001 \\
\hline & $(0.29)$ & $(0.56)$ & $(0.78)$ & $(1.67)$ & $(-1.54)$ & $(0.55)$ & $(-1.55)$ & $(-1.23)$ & $(-1.16)$ & $(0.14)$ & $(-3.80)$ & $(-1.50)$ \\
\hline \multirow[t]{2}{*}{ GROWTH } & $-0.013 * * *$ & $-0.013 * * *$ & $-0.013 * * *$ & $-0.011 * * *$ & $-0.015 * * *$ & $-0.013 * * *$ & $-0.012 * * *$ & $-0.012 * * *$ & $-0.012 * * *$ & $-0.009 * * *$ & $-0.014 * * *$ & $-0.011 * * *$ \\
\hline & $(-17.27)$ & $(-16.87)$ & $(-16.80)$ & $(-14.97)$ & $(-17.87)$ & $(-16.42)$ & $(-17.62)$ & $(-17.12)$ & $(-17.08)$ & $(-14.76)$ & $(-18.22)$ & $(-16.53)$ \\
\hline \multirow[t]{2}{*}{ DEBT } & -0.002 & -0.002 & -0.002 & 0.000 & -0.002 & 0.000 & $-0.004 * * *$ & $-0.004 * * *$ & $-0.004 * * *$ & $-0.003 * *$ & $-0.004 * * *$ & $-0.002 *$ \\
\hline & $(-1.13)$ & $(-1.29)$ & $(-1.16)$ & $(-0.32)$ & $(-1.20)$ & $(-0.21)$ & $(-2.94)$ & $(-3.08)$ & $(-3.00)$ & $(-1.89)$ & $(-3.05)$ & $(-1.80)$ \\
\hline ROA & $0.032 * * *$ & $0.033 * * *$ & $0.032 * * *$ & $0.033 * * *$ & $0.031 * * *$ & $0.027 * * *$ & $0.033 * * *$ & $0.035 * * *$ & $0.034 * * *$ & $0.034 * * *$ & $0.032 * * *$ & $0.028 * * *$ \\
\hline \multirow[t]{2}{*}{ RE_TE } & $0.001 * * *$ & $0.001 * * *$ & $0.001 * * *$ & $0.001 * * *$ & $0.001 * * *$ & $0.001 * * *$ & $0.001 * * *$ & $0.001 * * *$ & $0.001 * * *$ & $0.001 * * *$ & $0.001 * * *$ & $0.001 * * *$ \\
\hline & $(8.10)$ & $(7.81)$ & (7.01) & (6.28) & (8.46) & $(4.50)$ & $(8.48)$ & $(8.22)$ & (7.68) & $(6.35)$ & (8.92) & (4.87) \\
\hline \multirow[t]{2}{*}{ TAXE } & $-0.002 * * *$ & & & & & $-0.002 * * *$ & $-0.002 * * *$ & & & & & $-0.002 * * *$ \\
\hline & $(-6.00)$ & & & & & (4.88) & $(-7.68)$ & & & & & $(-6.46)$ \\
\hline \multirow[t]{2}{*}{ R_D } & & -0.004 & & & & $-0.008 *$ & & -0.001 & & & & -0.007 \\
\hline & & $(-0.69)$ & & & & $(-1.64)$ & & $(-0.26)$ & & & & $(-1.42)$ \\
\hline \multirow[t]{2}{*}{ SROA } & & & $-0.008 * * *$ & & & $-0.009 * *$ & & & $-0.005^{* *}$ & & & $-0.006 * *$ \\
\hline & & & $(-2.96)$ & & & $(-3.30)$ & & & $(-1.97)$ & & & $(-2.39)$ \\
\hline \multirow[t]{2}{*}{ AGE } & & & & $0.000 * * *$ & & $0.000 * * *$ & & & & $0.000 * * *$ & & $0.000 * * *$ \\
\hline & & & & (10.29) & & (10.59) & & & & $(12.45)$ & & (12.97) \\
\hline \multirow[t]{2}{*}{ MTB } & & & & & $0.001 * * *$ & $0.001 * * *$ & & & & & $0.001 * * *$ & $0.001 * * *$ \\
\hline & & & & & (5.78) & (6.57) & & & & & (6.47) & $(7.12)$ \\
\hline Year effects & Yes & Yes & Yes & Yes & Yes & Yes & Yes & Yes & Yes & Yes & Yes & Yes \\
\hline Industry & Yes & Yes & Yes & Yes & Yes & Yes & Yes & Yes & Yes & Yes & Yes & Yes \\
\hline Adj. R2 \% & 27.55 & 27.42 & 27.49 & 29.65 & 28.12 & 30.74 & 27.85 & 27.65 & 27.68 & 30.94 & 28.74 & 32.44 \\
\hline
\end{tabular}


This table examines the robustness of the results in Table 6 Model 2 and 8 to omitted variables for the 22,389 firm-year observations of the sample. CSR is measured as the overall CSR score. The dependent variables are the ratio of cash dividends to net sales (Models 1-6) and the ratio of cash dividends to total assets (Models 7-12). The control variables are size (SIZE), cash (CASH), sales growth (GROWTH), firm debt (DEBT), return on assets (ROA), and the ratio of retained earnings to common equity (RE_TE). Additional control variables are a dummy for whether a firm has a tax advantage (TAXE in Model 1 and 7), research and development to total assets (R_D in Model 2 and 8), the return on assets volatility (SROA in Model 3 and 9), the age (AGE in Model 4 and 10), the market to book ratio (MTB in Model 5 and 11). Models 6 and 12 include all the additional variables. Appendix B outlines the definitions for all the regression variables. All financial variables have been winsorized at the 5\% level. Unreported industry controls are based on the two-digit code of the Standard Industrial Classification. Financial firms (SIC codes 6000-6999) and utility firms (sic between 4900 and 4999) are excluded from the analysis. Robust t-statistics corrected for clustering at the firm level are presented in parentheses.

*statistical significance at the $10 \%$ level.

$* *$ statistical significance at the $5 \%$ level.

***statistical significance at the $1 \%$ level. 
Table 14: Robustness tests: instrumental variables to address the endogeneity

\begin{tabular}{|c|c|c|c|c|}
\hline & \multicolumn{2}{|c|}{ DIV_SALES } & \multicolumn{2}{|c|}{ DIV_ASSETS } \\
\hline & First stage & Second stage & First stage & Second stage \\
\hline & (1) & (2) & (3) & (4) \\
\hline \multirow{2}{*}{ INTERCEPT } & $-1.897^{*}$ & 0.016 & -1.814 & $0.008^{* *}$ \\
\hline & $(-1.72)$ & (1.29) & $(-1.50)$ & $(2.30)$ \\
\hline \multirow[t]{2}{*}{ CSR_NET } & & $0.002 * * *$ & & $0.002 * * *$ \\
\hline & & $(9.01)$ & & (10.18) \\
\hline \multirow[t]{2}{*}{ SIZE } & $0.250 * * *$ & $0.001 * * *$ & $0.259 * * *$ & $0.000 *$ \\
\hline & (6.94) & $(5.42)$ & (7.19) & $(1.75)$ \\
\hline \multirow[t]{2}{*}{ CASH } & $0.805 * * *$ & -0.001 & $0.836^{* * *}$ & $-0.004 * * *$ \\
\hline & $(4.56)$ & $(-0.99)$ & $(4.73)$ & $(-3.01)$ \\
\hline \multirow[t]{2}{*}{ GROWTH } & 0.099 & $-0.013 * * *$ & 0.103 & $-0.012 * * *$ \\
\hline & $(1.05)$ & $(-17.02)$ & (1.10) & $(-17.30)$ \\
\hline \multirow[t]{2}{*}{ DEBT } & -0.296 & -0.001 & -0.266 & $-0.003 * *$ \\
\hline & $(-1.62)$ & $(-0.61)$ & $(-1.46)$ & $(-2.38)$ \\
\hline \multirow[t]{2}{*}{ ROA } & $0.598 * * *$ & $0.031 * * *$ & $0.529 * *$ & $0.033 * * *$ \\
\hline & $(2.71)$ & $(13.55)$ & $(2.48)$ & (14.54) \\
\hline \multirow[t]{2}{*}{ RE_TE } & 0.026 & $0.001 * * *$ & 0.024 & $0.001 * * *$ \\
\hline & $(1.24)$ & $(7.26)$ & $(1.17)$ & (7.58) \\
\hline \multirow[t]{2}{*}{ CSR_IND } & $0.867 * * *$ & & $0.865 * * *$ & \\
\hline & (19.03) & & $(18.95)$ & \\
\hline \multirow[t]{2}{*}{ CSR_INI } & $0.618 * * *$ & & $0.617 * * *$ & \\
\hline & $(20.52)$ & & $(20.49)$ & \\
\hline Year effects & Yes & Yes & Yes & Yes \\
\hline Industry & Yes & Yes & Yes & Yes \\
\hline Adj. R2 \% & 34.88 & 29.39 & 34.89 & 30.05 \\
\hline $\mathrm{N}$ & 22,389 & 22,389 & 22,389 & 22,389 \\
\hline
\end{tabular}

This table presents results of instrumental variable estimation that controls for the endogeneity of CSR. Model 1-2 study the endogeneity for the regression of dividend payout on overall CSR score and control variables. Dividends are measured as the ratio of dividends to net sales. Model 3-4 study the endogeneity for the regression of dividend payout on overall CSR score and control variables. Dividends are measured as the ratio of cash dividends to total assets. We employ two instrumental variables: the first one is the industry-year average of overall CSR score, and the second one is the firm-level initial value of overall CSR score. The control variables are size (SIZE), cash (CASH), sales growth (GROWTH), firm debt (DEBT), return on assets (ROA), and the ratio of retained earnings to common equity (RE_TE). Appendix B outlines the definitions for all the regression variables. All financial variables have been winsorized at the 5\% level. Unreported industry controls are based on the two-digit code of the Standard Industrial Classification. Financial firms (SIC codes 6000-6999) and utility firms (sic between 4900 and 4999) are excluded from the analysis. Robust t-statistics corrected for clustering at the firm level are presented in parentheses.

*statistical significance at the $10 \%$ level.

**statistical significance at the $5 \%$ level.

***statistical significance at the $1 \%$ level. 
Table 15. Robustness tests: Propensity Score Matching

\begin{tabular}{|c|c|c|c|c|c|c|c|c|}
\hline & \multicolumn{4}{|c|}{ Dependent variable: DIV_SALES } & \multicolumn{4}{|c|}{ Dependent variable: DIV_ASSETS } \\
\hline Propensity Score Matching Estimation & Treated & Controls & Difference & T-stat & Treated & Controls & Difference & T-stat \\
\hline 1-1 Matching without replacement & 0.011 & 0.008 & $35.46 \% * * *$ & 13.99 & 0.011 & 0.008 & $39.39 \% * * *$ & 15.94 \\
\hline 1-1 Matching with replacement & 0.012 & 0.011 & $7.20 \% * *$ & 2.38 & 0.012 & 0.011 & $8.85 \% * *$ & 2.58 \\
\hline Nearest neighbor $(\mathrm{n}=2)$ & 0.012 & 0.011 & $10.25 \% * * *$ & 3.15 & 0.012 & 0.010 & $11.91 \% * * *$ & 3.79 \\
\hline \multirow[t]{5}{*}{ Nearest neighbor $(n=3)$} & 0.012 & 0.011 & $9.62 \% * * *$ & 3.01 & 0.012 & 0.010 & $11.20 \% * * *$ & 3.71 \\
\hline & \multicolumn{4}{|c|}{ Dependent variable: DIV_SALES } & \multicolumn{4}{|c|}{ Dependent variable: DIV_ASSETS } \\
\hline & PSM :1:1 & PSM:1:1 & PSM: & PSM: & PSM $: 1: 1$ & PSM:1:1 & PSM: & PSM: \\
\hline & $\begin{array}{l}\text { Matching } \\
\text { without } \\
\text { replacement }\end{array}$ & $\begin{array}{l}\text { Matching } \\
\text { with } \\
\text { replacement }\end{array}$ & $\begin{array}{l}\text { Nearest } \\
\text { neighbor } \\
(\mathrm{n}=2)\end{array}$ & $\begin{array}{l}\text { Nearest } \\
\text { neighbor } \\
(\mathrm{n}=3)\end{array}$ & $\begin{array}{l}\text { Matching } \\
\text { without } \\
\text { replacement }\end{array}$ & $\begin{array}{l}\text { Matching } \\
\text { with } \\
\text { replacement }\end{array}$ & $\begin{array}{l}\text { Nearest } \\
\text { neighbor } \\
(\mathrm{n}=2)\end{array}$ & $\begin{array}{l}\text { Nearest } \\
\text { neighbor } \\
(n=3)\end{array}$ \\
\hline & $(1)$ & (2) & (3) & (4) & $(5)$ & $(6)$ & $(7)$ & (8) \\
\hline INTERCEPT & $\begin{array}{c}-0.005 * * \\
(-2.07)\end{array}$ & $\begin{array}{l}-0.003 \\
(-1.33)\end{array}$ & $\begin{array}{c}0.017 * * * \\
(6.92)\end{array}$ & $\begin{array}{c}-0.004 * * \\
(-2.21)\end{array}$ & $\begin{array}{c}0.006 * * * \\
(2.80)\end{array}$ & $\begin{array}{c}0.005 * * \\
(2.06)\end{array}$ & $\begin{array}{c}0.035 * * * \\
(17.24)\end{array}$ & $\begin{array}{l}0.003 \\
(1.74)\end{array}$ \\
\hline CSR_NET & $\begin{array}{c}0.001 * * * \\
(4.14)\end{array}$ & $\begin{array}{c}0.001 * * * \\
(3.96)\end{array}$ & $\begin{array}{c}0.001 * * * \\
(4.93)\end{array}$ & $\begin{array}{c}0.001 * * * \\
(4.84)\end{array}$ & $\begin{array}{c}0.001 * * * \\
(4.49)\end{array}$ & $\begin{array}{c}0.001 * * * \\
(4.17)\end{array}$ & $\begin{array}{c}0.001 * * * \\
(5.29)\end{array}$ & $\begin{array}{c}0.001 * * * \\
(5.38)\end{array}$ \\
\hline SIZE & $\begin{array}{c}0.002 * * * \\
(5.85)\end{array}$ & $\begin{array}{c}0.002 * * * \\
(6.16)\end{array}$ & $\begin{array}{c}0.002 * * * \\
(6.68)\end{array}$ & $\begin{array}{c}0.002 * * * \\
(6.91)\end{array}$ & $\begin{array}{c}0.001 * * * \\
(3.10)\end{array}$ & $\begin{array}{c}0.001 * * * \\
(3.39)\end{array}$ & $\begin{array}{c}0.001 * * * \\
(3.76)\end{array}$ & $\begin{array}{c}0.001 * * * \\
(3.85)\end{array}$ \\
\hline CASH & $\begin{array}{l}0.000 \\
(0.05)\end{array}$ & $\begin{array}{c}0.000 \\
(-0.14)\end{array}$ & $\begin{array}{l}0.000 \\
(0.23)\end{array}$ & $\begin{array}{l}0.001 \\
(0.36)\end{array}$ & $\begin{array}{c}-0.003^{*} \\
(-1.75)\end{array}$ & $\begin{array}{c}-0.002 * * * \\
(-1.57)\end{array}$ & $\begin{array}{l}-0.002 \\
(-1.50)\end{array}$ & $\begin{array}{c}-0.002 * * * \\
(-1.51)\end{array}$ \\
\hline GROWTH & $\begin{array}{c}-0.013 * * * \\
(-13.45)\end{array}$ & $\begin{array}{c}-0.013 * * * \\
(-12.37)\end{array}$ & $\begin{array}{c}-0.013 * * * \\
(-14.02)\end{array}$ & $\begin{array}{c}-0.013 * * * \\
(-14.57)\end{array}$ & $\begin{array}{c}-0.011 * * * \\
(-13.62)\end{array}$ & $\begin{array}{c}-0.012 * * * \\
(-12.39)\end{array}$ & $\begin{array}{c}-0.012 * * * \\
(-14.34)\end{array}$ & $\begin{array}{c}-0.011 * * * \\
(-14.91)\end{array}$ \\
\hline DEBT & $\begin{array}{l}-0.003 \\
(-1.43)\end{array}$ & $\begin{array}{c}-0.003^{*} \\
(-1.75)\end{array}$ & $\begin{array}{c}-0.003^{*} \\
(-1.66)\end{array}$ & $\begin{array}{l}-0.002 \\
(-1.38)\end{array}$ & $\begin{array}{c}-0.005^{* * *} \\
(-3.14)\end{array}$ & $\begin{array}{c}-0.005^{* * *} \\
(-3.21)\end{array}$ & $\begin{array}{c}-0.005^{* * *} * \\
(-3.58)\end{array}$ & $\begin{array}{c}-0.005 * * * \\
(-3.29)\end{array}$ \\
\hline ROA & $\begin{array}{c}0.032 * * * \\
(11.11)\end{array}$ & $\begin{array}{c}0.032 * * * \\
(10.43)\end{array}$ & $\begin{array}{c}0.032 * * * \\
(11.88)\end{array}$ & $\begin{array}{c}0.032 * * * \\
(12.48)\end{array}$ & $\begin{array}{c}0.034 * * * \\
(12.18)\end{array}$ & $\begin{array}{c}0.033 * * * \\
(11.43)\end{array}$ & $\begin{array}{c}0.033 * * * \\
(12.85)\end{array}$ & $\begin{array}{c}0.033^{* * * *} \\
(13.44)\end{array}$ \\
\hline RE_TE & $\begin{array}{c}0.001 * * * \\
(7.53)\end{array}$ & $\begin{array}{c}0.001 * * * \\
(6.55)\end{array}$ & $\begin{array}{c}0.001 * * * \\
(7.74)\end{array}$ & $\begin{array}{c}0.001 * * * \\
(7.73)\end{array}$ & $\begin{array}{c}0.001 * * * \\
(7.77)\end{array}$ & $\begin{array}{c}0.001 * * * \\
(6.77)\end{array}$ & $\begin{array}{c}0.001 * * * \\
(6.77)\end{array}$ & $\begin{array}{c}0.001 * * * \\
(8.07)\end{array}$ \\
\hline Year effects & Yes & Yes & Yes & Yes & Yes & Yes & Yes & Yes \\
\hline Industry effects & Yes & Yes & Yes & Yes & Yes & Yes & Yes & Yes \\
\hline Adj. R2 \% & 24.09 & 24.40 & 24.50 & 24.49 & 24.07 & 24.10 & 24.77 & 24.85 \\
\hline
\end{tabular}


This table reports the difference in dividend payout (using two measures of dividend payout, namely, cash dividends to net sales and cash dividends to total assets), between high and low CSR firms, estimated by propensity score matching (PSM) with four different matching methods. The propensity scores are computed from a probit model using the same variables as in our main effects model and two instrumental variables. The instrumental variables are the industry-year average of overall CSR score, and the firm-level initial value of overall CSR score. The table also shows regression estimates of the relation between overall CSR score and firm dividend payout using the matched samples obtained via the four propensity score methods: 1-1 matching without replacement (Models 1 and 5), 1-1 matching with replacement (Models 2 and 6), nearest neighbor $(n=2)$ (Models 3 and7), and nearest neighbor $(n=3)$ (Models 4 and 8). The dependent variables are dividends to net sales (Models 1-4) and dividends to total assets (Models 5-8). The control variables (used in the propensity score matching as well as in the regressions) are size (SIZE), cash (CASH), sales growth (GROWTH), firm debt (DEBT), return on assets (ROA), and the ratio of retained earnings to common equity (RE_TE). Appendix $\mathrm{B}$ outlines the definitions for all the regression variables. All financial variables have been winsorized at the $5 \%$ level. Unreported industry controls are based on the two-digit code of the Standard Industrial Classification. Financial firms (SIC codes 6000-6999) and utility firms (sic between 4900 and 4999 ) are excluded from the analysis. Robust t-statistics corrected for clustering at the firm level are presented in parentheses.

*statistical significance at the $10 \%$ level.

$* *$ statistical significance at the $5 \%$ level.

***statistical significance at the $1 \%$ level. 
Table 16. Robustness tests: Heckman Selection Model

\begin{tabular}{|c|c|c|c|}
\hline & \multicolumn{3}{|c|}{ Dividends } \\
\hline & Selection equation & Outcome equation & Outcome equation \\
\hline & CSR_NET & DIV_SALES & DIV_ASSETS \\
\hline & $\overline{(1)}$ & $(2)$ & $(3)$ \\
\hline INTERCEPT & $-0.716^{* * *}$ & 0.011 & 0.004 \\
\hline & $(-10.03)$ & $(1.07)$ & $(1.22)$ \\
\hline CSR_SCORE & & $\begin{array}{c}0.001 * * * \\
(5.33)\end{array}$ & $\begin{array}{c}0.001 * * * \\
(5.33)\end{array}$ \\
\hline SIZE & $\begin{array}{c}0.077 * * * \\
(9.89)\end{array}$ & $\begin{array}{c}0.002 * * * \\
(7.87)\end{array}$ & $\begin{array}{c}0.001 * * * \\
(4.33)\end{array}$ \\
\hline $\mathrm{CASH}$ & $\begin{array}{c}0.326 * * * \\
(5.05)\end{array}$ & $\begin{array}{l}0.001 \\
(0.35)\end{array}$ & $\begin{array}{l}-0.002 \\
(-1.52)\end{array}$ \\
\hline GROWTH & $\begin{array}{l}0.039 \\
(0.65)\end{array}$ & $\begin{array}{c}-0.013 * * * \\
(-16.99)\end{array}$ & $\begin{array}{c}-0.011 * * * \\
(-17.25)\end{array}$ \\
\hline DEBT & $\begin{array}{c}-0.311 * * * \\
(-4.87)\end{array}$ & $\begin{array}{c}-0.002 * * * \\
(-1.23)\end{array}$ & $\begin{array}{c}-0.004 * * * \\
(-2.97)\end{array}$ \\
\hline ROA & $\begin{array}{l}0.151 \\
(1.38)\end{array}$ & $\begin{array}{c}0.033 * * * \\
(13.92)\end{array}$ & $\begin{array}{c}0.035^{* * *} \\
(14.76)\end{array}$ \\
\hline RE_TE & $\begin{array}{c}0.024 * * \\
(2.61)\end{array}$ & $\begin{array}{c}0.001 * * * \\
(8.26)\end{array}$ & $\begin{array}{c}0.001 * * * \\
(8.52)\end{array}$ \\
\hline CSR_IND & $\begin{array}{c}0.485 * * * \\
(22.85)\end{array}$ & & \\
\hline CSR_INI & $\begin{array}{c}0.342 * * * \\
(49.78)\end{array}$ & & \\
\hline INV_MILLS & & $\begin{array}{c}0.006 \\
0.20\end{array}$ & $\begin{array}{l}-0.00 \\
-0.34\end{array}$ \\
\hline Year effects & Yes & Yes & Yes \\
\hline Industry & Yes & Yes & Yes \\
\hline Adj. R2 \% & & 27.41 & 27.65 \\
\hline $\mathrm{N}$ & 22,389 & 22,389 & 22,389 \\
\hline
\end{tabular}

This tables reports the results of Heckman's two-step treatment effect model used to correct the self-selection in CSR. The selection (CSR score) equation uses CSR Dummy as the dependent variable that takes the value of 1 if the firm has a positive overall CSR score, and 0 otherwise. We employ two instrumental variables: the industryyear average of overall CSR scores (CSR_IND), and the firm-level initial value of overall CSR scores (CSR_INI). The outcome equations use as dependent variables: the ratio of cash dividends to net sales (Model 2) and the ratio of cash dividends to total assets (Model 3). The outcome equation controls the inverse Mills ratio (INV_MILLS) estimated from the selection equation. The control variables are size (SIZE), cash (CASH), sales growth (GROWTH), firm debt (DEBT), return on assets (ROA), and the ratio of retained earnings to common equity (RE_TE). Appendix B outlines the definitions for all the regression variables. All financial variables have been winsorized at the 5\% level. Unreported industry controls are based on the two-digit code of the Standard Industrial Classification. Financial firms (SIC codes 6000-6999) and utility firms (sic between 4900 and 4999) are excluded from the analysis. Robust t-statistics corrected for clustering at the firm level are presented in parentheses.

*statistical significance at the $10 \%$ level.

**statistical significance at the $5 \%$ level.

***statistical significance at the $1 \%$ level. 